九州大学学術情報リポジトリ

Kyushu University Institutional Repository

\title{
A Revision of the Genus Tetrugnatha Latreille (Araneae, Tetragnathidae) of Asia, Part II
}

Okuma, Chiyoko

Entomological Laboratory, Faculty of Agriculture, Kyushu University

https://doi.org/10.5109/23877

出版情報：九州大学大学院農学研究院紀要. 32 (3/4)，pp. 183-213，1988-03. Kyushu University バージョン：

権利関係: 


\title{
A Revision of the Genus Tetrugnatha Latreille (Araneae, Tetragnathidae) of Asia, Part II*
}

\author{
Chiyoko 0 kuma \\ Entomological Laboratory, Faculty of Agriculture, \\ Kyushu University, Fukuoka 812 \\ (Received September 24, 1987)
}

\begin{abstract}
This paper (Part II) includes the species of the major group B of Tetragnatha of Asia. New records of distribution are as follows : T. mandibulata and T. maxillosa from Bangladesh, T. hasselti from Bangladesh and Thailand, T.vermiformis from Bangladesh and Malaysia, $T$. geniculata and T.serra from Thailand, T. chauliodus from Philippines and Taiwan and $T$. lauta from Taiwan and Hong Kong.
\end{abstract}

\section{The squamata-group}

Diagnosis. Male chelicera well developed, fang with an outer cusp near base, tip of (a) simply pointed, (Gl) robust, with a tubercle or 2-3 tubercles ; female chelicera small, without particular features.

\section{KEY TO THE SPECIES}

Male

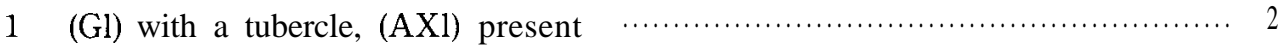

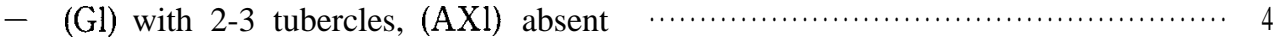

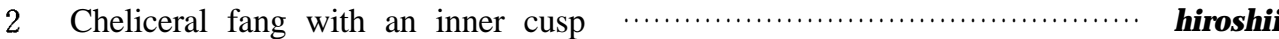

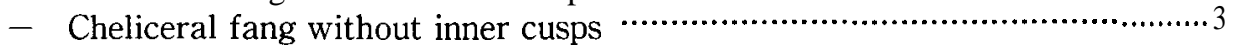

3 (U2) widely separated from $(\mathrm{Gu})$, situated about the middle of chelicera

- (U2) not so widely separated from (Gu), situated beyond the middle of

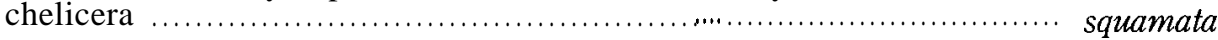

4 (U2) widely separated from (Gu), situated about the middle of chelicera

- (U2) rather close to $(\mathrm{Gu})$, situated beyond the middle of chelicera ……....esakii

Tetragnatha hiroshii Okuma, 1988

(Fig. 1, Table 1)

Tetragnatha hiroshii Okuma, 1988, Esakia, (26) : 72.

Distribution : Taiwan.

* Contribuion from the Entomological Laboratory, Faculty of Agriculture, Kyushu University, Fukuoka (Ser. 3, No. 257). 


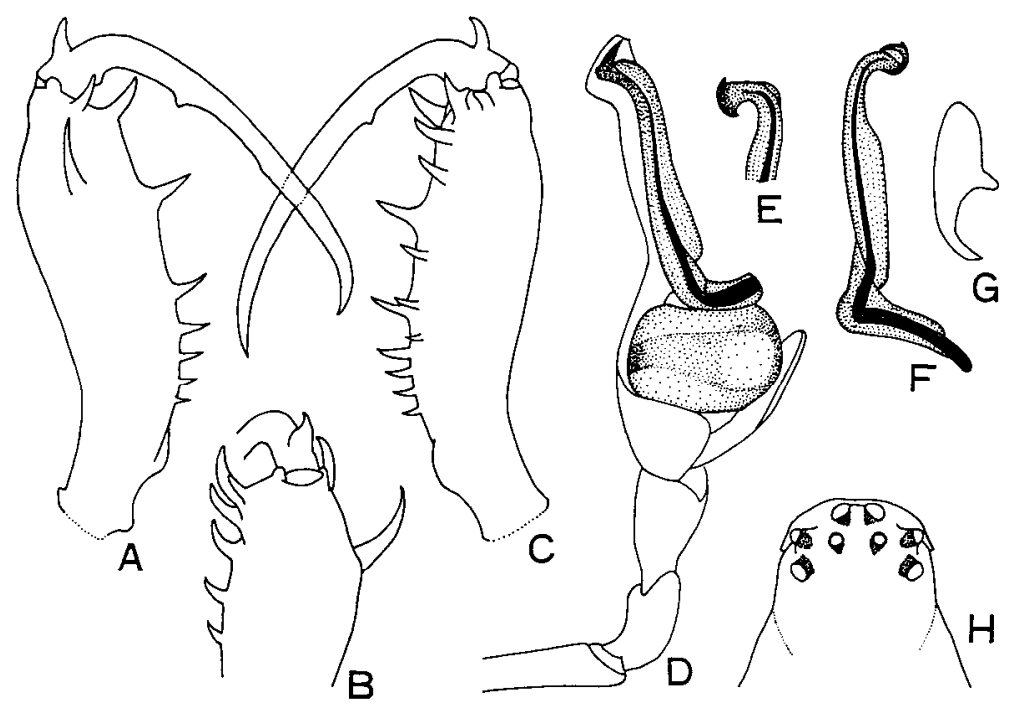

Fig. 1. Tetragnatha hiroshii Okuma. A : Left chelicera of male, upper view. B : Ditto, lateral view. C : Ditto, lower view. D : Left palpus of male. E and F : Conductor and embolus of male. G: Paracymbium of male. H : Eye group of male. (After Okuma, 1988).

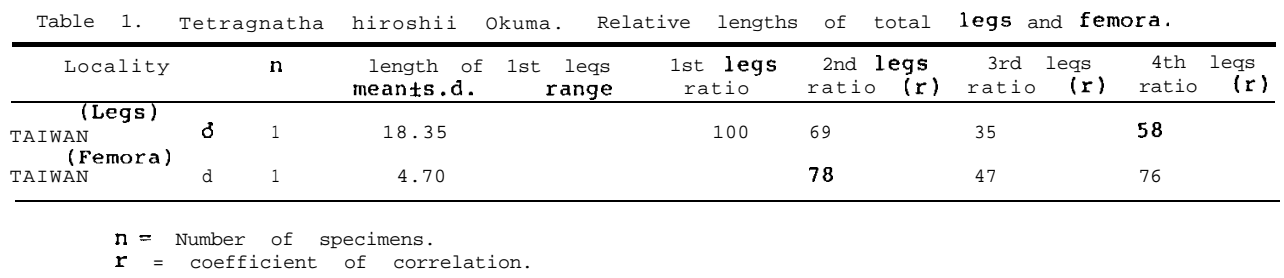

Note : This species is very similar to $\boldsymbol{T}$. squamata Karsch and T. tunigawai Okuma in many respects, but is easily separable from them by having an inner cusp on the chericeral fang in the male. The shape of the male conductor is also different from those of squamata and tunigawai. Carapacial length : male $1.9 \mathrm{~mm}$.

Tetragnatha tanigawai Okuma, 1988

(Fig. 2, Table 2)

Tetragnatha tanigawai Okuma, 1988, Esakia, (26) : 73.

Distribution : Iriomote Is. of the Ryukyus, Japan.

Note : This species is very similar to $\boldsymbol{T}$. squamata Karsch in many respects, but is easily separable from the latter in having a pair of small blackish markings near the spinnerets in both sexes. In addition, the number of spines on legs different from the latter (first femur with 2-3 spines in tanigawai, whereas that of squamata with 6-7), and 


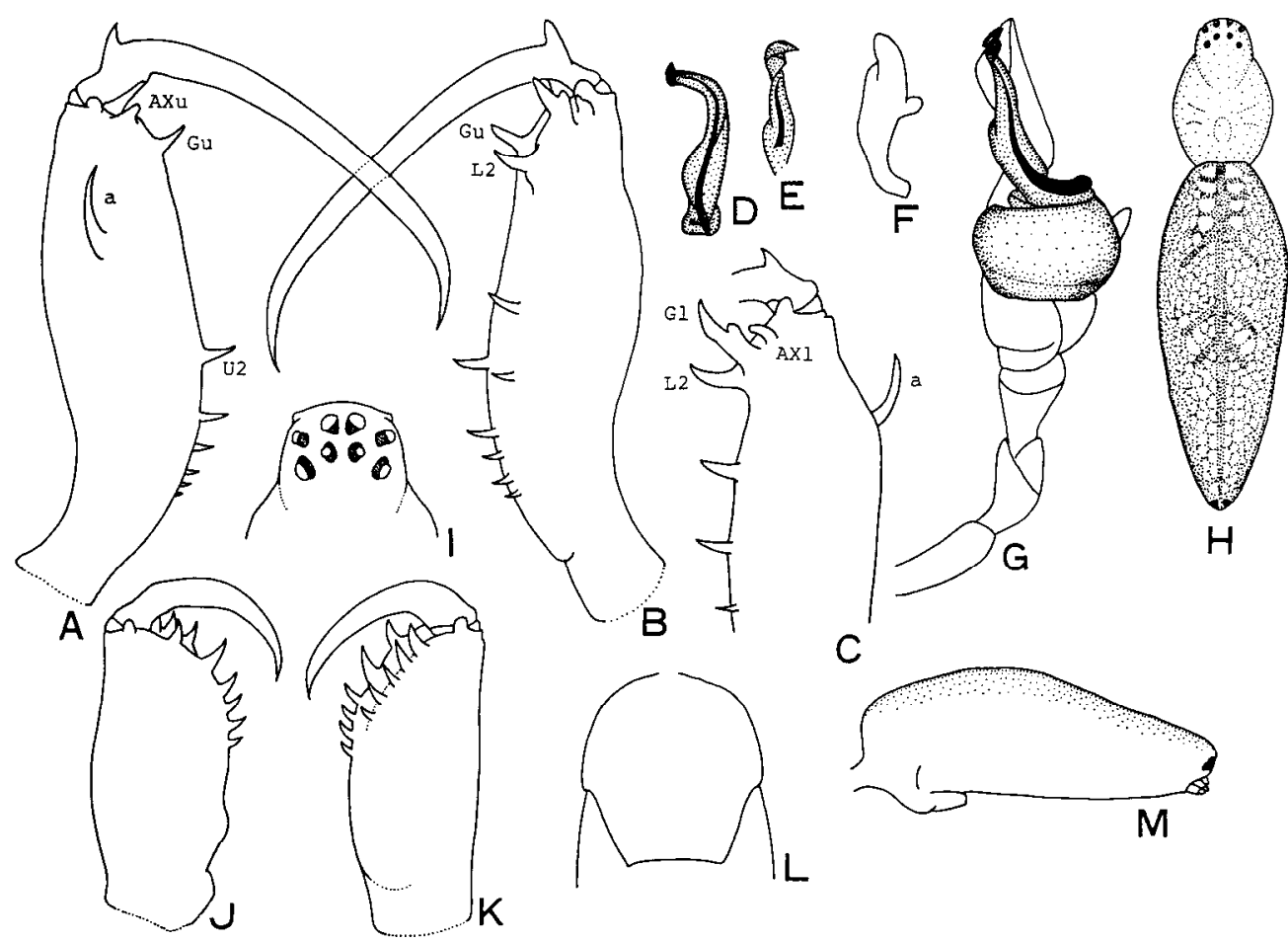

Fig. 2. Tetragnatha tanigawai Okuma. A: Left chelicera of male, upper view. B: Ditto, lower view. C : Ditto, lateral view. D and E : Conductor and embolus of male. F : Paracymbium of male. G : Left palpus of male. H : Female. I : Eye group of female. J : Left chelicera of female, upper view. K : Ditto, lower view. L : Genital fold of female. M : Abdomen of female, lateral view. (After Okuma, 1988).

Table 2. Tetragnatha tanigawai Okuma. Relative lengths of total legs and femora.

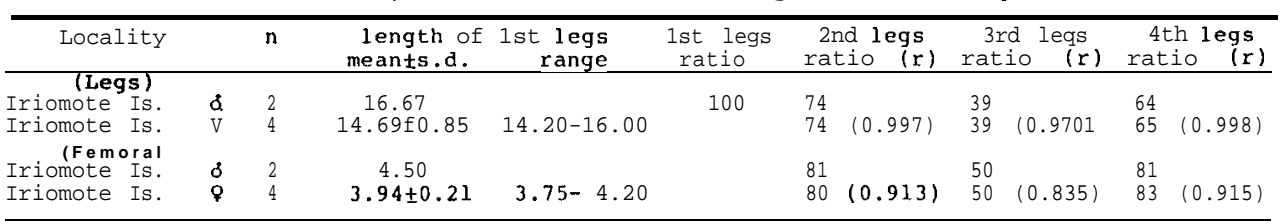

the arrangement of cheliceral teeth in the male also somewhat different from that of the latter. Body length : male 4.8-5.1 mm, female 5.2-5.8 mm.

Tetragnatha yesoensis Saito, 1934

(Fig. 3, Table 3)

Tetragnatha yesoensis Saito, 1934, J. Agr. Hokkaido Univ., 33: 334 ; Yaginuma, 1960, Spiders of Japan in Colour, : 73. 


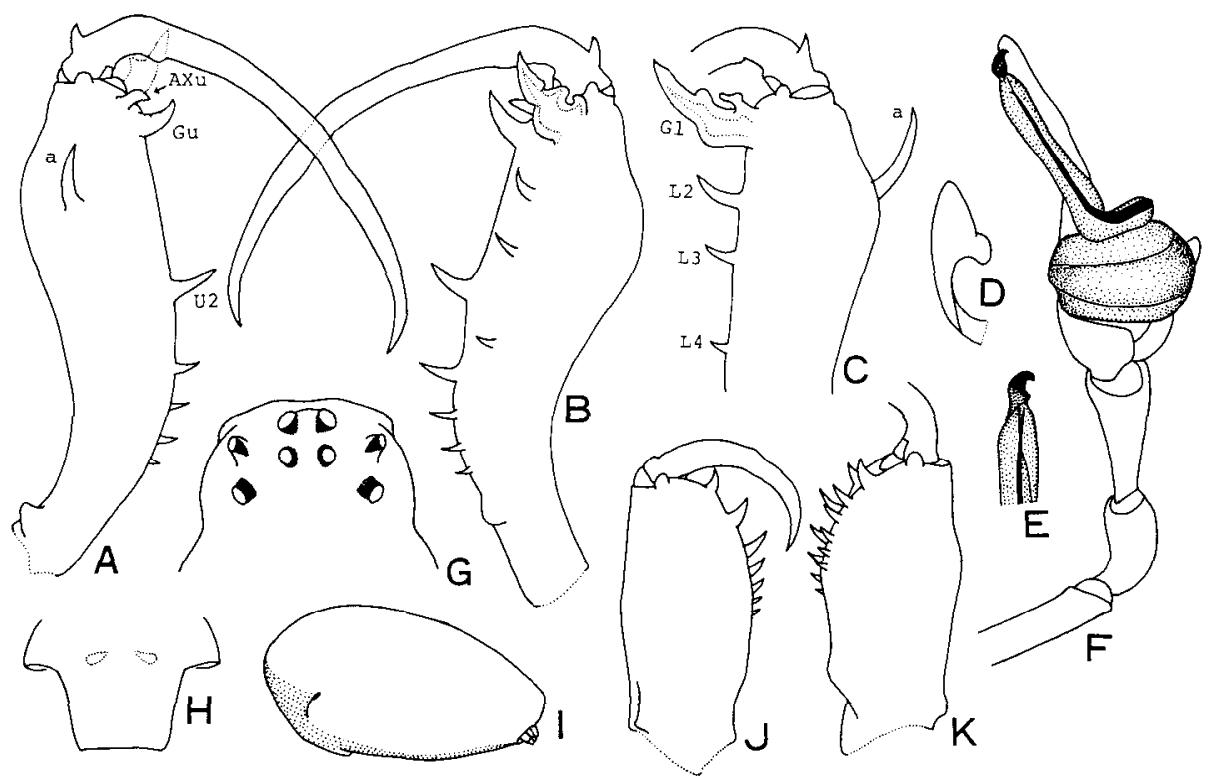

Fig. 3. Tetragnatha yesoensis Saito. A : Left chelicera of male, upper view. B : Ditto, lower view. C: Ditto, lateral view. D: Paracymbium of male. E: Distal portion of conductor and embolus of male. F: Left palpus of male. G: Eye group of male. $\mathrm{H}$ : Genital fold of female. I : Abdomen of female, lateral view. J : Left chelicera of female, upper view. K : Ditto, lower view.

Table 3. Tetragnatha yesoensis saito. Relative lengths of total legs and femora.

\begin{tabular}{|c|c|c|c|c|c|c|c|c|c|c|c|}
\hline Locality & & n & $\begin{array}{l}\text { length of } \\
\text { meants.d. }\end{array}$ & $\begin{array}{l}\text { 1st legs } \\
\mathrm{r} \text { a } \mathrm{n} \mathrm{g} \mathrm{e}\end{array}$ & $\begin{array}{l}\text { 1st legs } \\
\text { ratio }\end{array}$ & $\begin{array}{r}2 \mathrm{no} \\
\text { rati }\end{array}$ & $\begin{array}{l}d \\
\text { legs } \\
\text { io }\end{array}$ & & $\begin{array}{l}\text { d legs } \\
\text { tio (r) }\end{array}$ & $\begin{array}{l}4 \mathrm{th} \\
\text { rat }\end{array}$ & $\begin{array}{l}h \text { legs } \\
\text { io }(\mathrm{r})\end{array}$ \\
\hline (Legs) & 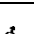 & & & & & & & & & & \\
\hline $\begin{array}{l}\text { Hokkaido } \\
\text { Nikko }\end{array}$ & 8 & $\begin{array}{r}10 \\
8\end{array}$ & $\begin{array}{l}18.81 \mathrm{f} 2.67 \\
20.64 \mathrm{f} 3.24\end{array}$ & $\begin{array}{l}14.40-23.40 \\
16.80-26.40\end{array}$ & 100 & 73 & $\begin{array}{c}(0.999) \\
(0.997)\end{array}$ & $\begin{array}{l}38 \\
38\end{array}$ & $(0.996)$ & $\begin{array}{l}59 \\
60\end{array}$ & $\begin{array}{l}(0.9951 \\
(0.994)\end{array}$ \\
\hline $\begin{array}{l}\text { Nikko } \\
\text { Tottori }\end{array}$ & $\delta$ & 13 & $22.38 f 2.29$ & $17.15-25.40$ & & $\begin{array}{l}73 \\
71\end{array}$ & $\begin{array}{l}(0.997) \\
(0.997)\end{array}$ & $\begin{array}{l}38 \\
37\end{array}$ & $(0.985)$ & 59 & $(0.993)$ \\
\hline Tsushima Is. & d & & 24.75 & & & 72 & & 37 & & 59 & \\
\hline Fukuoka & 8 & 11 & 22.63 & $-20.30-24.95$ & & 71 & & 37 & & 60 & \\
\hline Kumamoto & 8 & 4 & $24.45 i 1.11$ & $23.15-25.40$ & & 71 & $(0.989)$ & 36 & 1 & 58 & $(0.992)$ \\
\hline KOREA $(900 \mathrm{~m})$ & 3 & 4 & $21.90 f 1.87$ & $20.15-24.00$ & & 72 & ) & 37 & $(0.993)$ & 60 & $(0.998)$ \\
\hline KOREA $(500 \mathrm{~m})$ & o & 10 & $21.13 f 2.51$ & $16.80-23.95$ & & 72 & $(0.998)$ & 37 & $(0.993)$ & 59 & $(0.996)$ \\
\hline Hokkaido & Q & 5 & $14.09 f 1.86$ & $10.80-15.30$ & & 75 & $(0.999)$ & 41 & $(0.997)$ & 64 & $(0.988)$ \\
\hline Nikko & 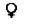 & 11 & $16.53 f 1.49$ & $14.45-19.60$ & & 73 & $(0.994)$ & 39 & $(0.967)$ & 62 & IO. 9891 \\
\hline Tottori & \& & 4 & $16.98 \pm 0.54$ & $16.20-17.40$ & & 73 & $(0.892)$ & 39 & $(0.828)$ & 62 & i0.985, \\
\hline Kumamoto & $Q$ & 7 & $18.61 \mathrm{f} 1.13$ & $17.10-20.00$ & & 72 & $(0.993)$ & 39 & $(0.986)$ & 62 & $\mathrm{Co} .9661$ \\
\hline KOREA $\quad(900 \mathrm{~m})$ & $Q$ & 3 & $15.75 f 1.92$ & $13.65-17.40$ & & 73 & $(1)$ & 40 & $(0.997)$ & 63 & $(1)$ \\
\hline 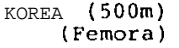 & $Q$ & 6 & $16.96 f 0.97$ & $15.65-18.55$ & & 73 & $(0.996)$ & 39 & $(0.979)$ & 62 & $(0.937)$ \\
\hline Hokkaido & 8 & 10 & $5.14 \mathrm{f0.73}$ & $4.00-6.40$ & & 79 & $(0.995)$ & 47 & $(0.985)$ & 72 & $(0.993)$ \\
\hline Nikko & 8 & 8 & $5.70 t 0.90$ & $4.50-7.25$ & & 79 & $(0.997)$ & 47 & $(0.985)$ & 72 & $(0.998)$ \\
\hline Tottori & $\delta$ & 13 & $6.09 \pm 0.60$ & $4.75-6.80$ & & 78 & $(0.993)$ & 46 & $(0.983)$ & 71 & $(0.991)$ \\
\hline Tsushima Is. & 8 & 1 & 6.75 & & & 77 & & 46 & & 70 & \\
\hline Fukuoka & 8 & 2 & 6.08 & $5.55-6.60$ & & 77 & & 47 & & 72 & \\
\hline Kumamoto & 8 & 4 & $6.66 f 0.36$ & $6.30-6.95$ & & 77 & $(0.976)$ & 46 & $(0.978)$ & 71 & $(0.986)$ \\
\hline KOREA $(900 \mathrm{~m})$ & 3 & 4 & $5.89 f 0.53$ & $5.40-6.50$ & & 78 & $(1)$ & 46 & $(0.920)$ & 72 & $(0.995)$ \\
\hline KOREA $(500 \mathrm{~m})$ & 8 & 10 & $5.72 \pm 0.68$ & $4.50-6.35$ & & 78 & $(0.996)$ & 46 & $(0.976)$ & 72 & $(0.976)$ \\
\hline Hokkaido & $Q$ & 5 & $3.97 i 0.49$ & $3.10-4.30$ & & 79 & $(0.992)$ & 49 & 10.999) & 76 & $(0.987)$ \\
\hline $\mathrm{Nikko}$ & $Q$ & 11 & $4.59 \pm 0.38$ & $4.05-5.30$ & & 79 & $(0.983)$ & 48 & $(0.963)$ & 75 & $(0.984)$ \\
\hline Tottori & $q$ & 4 & $4.68 f 0.09$ & $4.55-4.75$ & & 78 & $(0.953)$ & 48 & $(0.667)$ & 75 & $(0.7931$ \\
\hline Kumamoto & 8 & & $5.09 \pm 0.32$ & $4.70-5.50$ & & 78 & $(0,984)$ & 49 & $(0.993)$ & 75 & $(0.973)$ \\
\hline KOREA $(900 \mathrm{~m})$ & 9 & 13 & 4. $2 \mathrm{Bf} 0.58$ & $3.65-4.80$ & & 79 & $1 \quad 1$ & 49 & $(0.987)$ & 76 & $(0.999)$ \\
\hline KOREA $\quad(500 \mathrm{~m})$ & $Q$ & 6 & $4.66 \pm 0.27$ & $4.25-5.05$ & & 79 & $(0.995)$ & 48 & $(0.959)$ & 76 & $(0.845)$ \\
\hline
\end{tabular}


Male. Body length, exclusive of chelicerae, 3.9-7.6 mm ; carapacial length 1.5$2.8 \mathrm{~mm}$, width LO-1.7 mm ; abdominal length 2.3-5.0 mm, width 0.9-1.6 mm ; cheliceral length $1.3-2.9 \mathrm{~mm}$.

Eyes. Posterior row of eyes slightly narrower than anterior row of eyes ; viewed from above, two rows nearly parallel and gently recurved.

Chelicerae. Basal segment about as long as carapace ; (a) slender and pointed at tip ; $(\mathrm{AXu})$ pointed at tip, close to $(\mathrm{Gu})$, (U2) widely separated from $(\mathrm{Gu})$, situated about the middle of chelicera ; (rsu) 5-6 in number ; $(\mathrm{AXI})$ absent, (Gl) very large, with two tubercles, (rsl) about 3 in number ; fang with an outer cusp near base.

Legs. Leg formula 1. 2. 4. 3 ; all legs with spines, first femur with 5-7 spines ; relative lengths of legs as shown in Table 3.

Palpi. Paracymbium bluntly rounded at tip ; both conductor and embolus long, tip of conductor hook-like and distinctly twisted as shown in Fig. 3, E and F.

Abdomen. Not so long, less than 3 times as long as broad, distal end of abdomen somewhat overhanging spinnerets.

Color in alcohol. Generally yellowish brown ; abdomen covered with many silvery spangles.

Female. Body length, exclusive of chelicerae, $5.7-7.2 \mathrm{~mm}$; carapacial length 1.9-2.5 mm, width 1.2-1.6 $\mathrm{mm}$; abdominal length 3.6-4.8 mm, width $1.6-2.2 \mathrm{~mm}$; cheliceral length $0.9-1.1 \mathrm{~mm}$.

Eyes. Nearly as in male.

Chelicerae. Basal segment slightly shorter than one-half of carapace, without paticular features.

Legs. Nearly as in male, relative lengths of legs as shown in Table 3.

Abdomen. Not so long, less than 2.5 times as long as broad, somewhat swollen at the middle.

Color in alcohol. Similar to male.

Specimens examined : KOREA : 166, 9 우, Mt. Sudo-san, Gyongangbug-Do, 8. VI. 1977, K. Yamagishi. JAPAN : 15 specimens from Ehime (Ishizuchi-san), Tsushima Is. (Mine-mura and Mt. Oboshi-yama), Fukuoka (Mt. Hiko-san), Kumamoto (Mt. shiratori-yama); and many other specimens of both sexes from Hokkaido and Honshu.

Distribution : Japan and Korea (new record).

Tetragnatha esakii Okuma, 1988

(Fig. 4, Table 4)

Tetragnatha esakii Okuma, 1988, Esakia, (26):71.

Distribution : Taiwan.

Note : This species is very similar to $T$. yesoensis Saito in many respects, but is separable from the latter in the arrangement of cheliceral teeth in the male (the space between $(\mathrm{Gu})$ and (U2) is very long in yesoensis, and short in this species). The shapes of the male conductor and the male (EX) are also different from those of yesoensis. Body length : male 7.7-9.5 mm, female 7.4-9.3 $\mathrm{mm}$. 


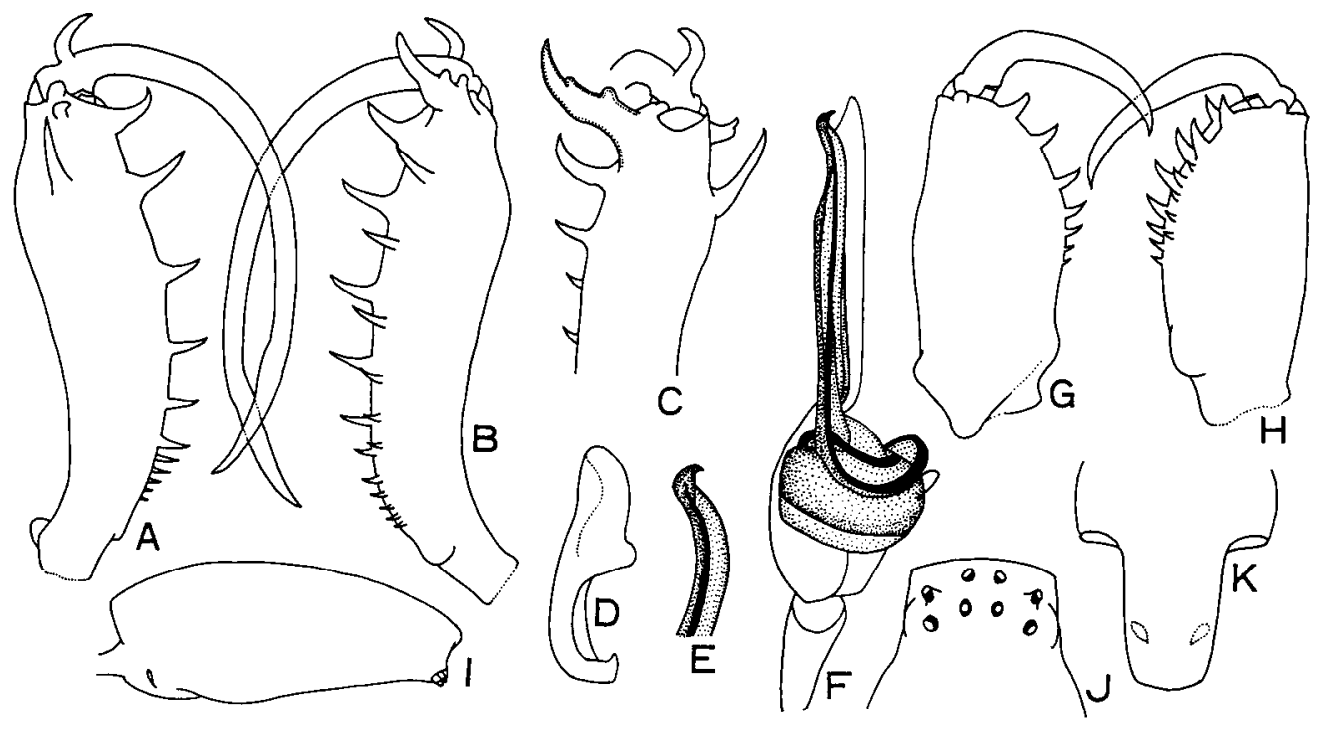

Fig. 4. Tetragnathu esakii Okuma. A : Left chelicera of male, upper view. B : Ditto, lower view. C : Ditto, lateral view. D : Paracymbium of male. E : Distal portion of conductor and embolus of male. F : Left palpus of male. G : Left chelicera of female, upper view. H : Ditto, lower view. I : Abdomen of female, lateral view. J : Eye group of female. K : Genital fold of female. (After Okuma, 1988).

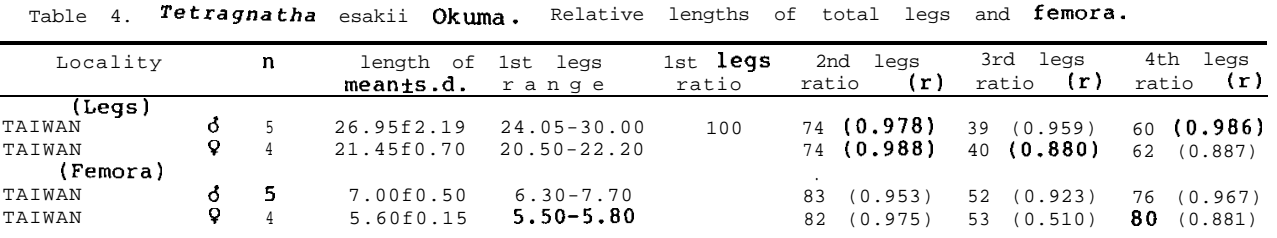

Tetragnatha squamata Karsch, 1879 (Fig. 5, Table 5)

Tetragnatha squamata Karsch, 1879, Verh. Nat. Ver. Rheinl. Westf., 36: 65; Strand, 1918, Archn. Naturg., 82 (A ; 11) : 95 ; Boesenberg et Strand, 1906, Abh. Senckenbg. Ges., 30 (1-2) : 176 ; Saito, 1934, Trans. Sapporo Nat. Hist. Soc., 13: 338; Saito, 1934, J. Agr. Hokkaido Univ., 33: 333; Saito Ho-on Kai Mus. Res. Bull., 18: 59; Yaginuma, 1960, Spiders of Japan in Colour,: 74 ; Okuma, 1985, Esakia, (23) : 41.

Male. Body length, exclusive of chelicerae 3.2-5.3 mm ; carapacial length 1.3-1.9 $\mathrm{mm}$, width 0.9-1.25 mm ; abdominal length $2.0-3.4 \mathrm{~mm}$, width $0.9-1.15 \mathrm{~mm}$; cheliceral length 1.1-1.5 mm.

Eyes. Posterior row of eyes slightly narrower than anterior row of eyes ; viewed from above, two rows nearly parallel and gently recurved.

Chelicerae. Basal segment about 0.8 times as long as carapace; (a) slender, 


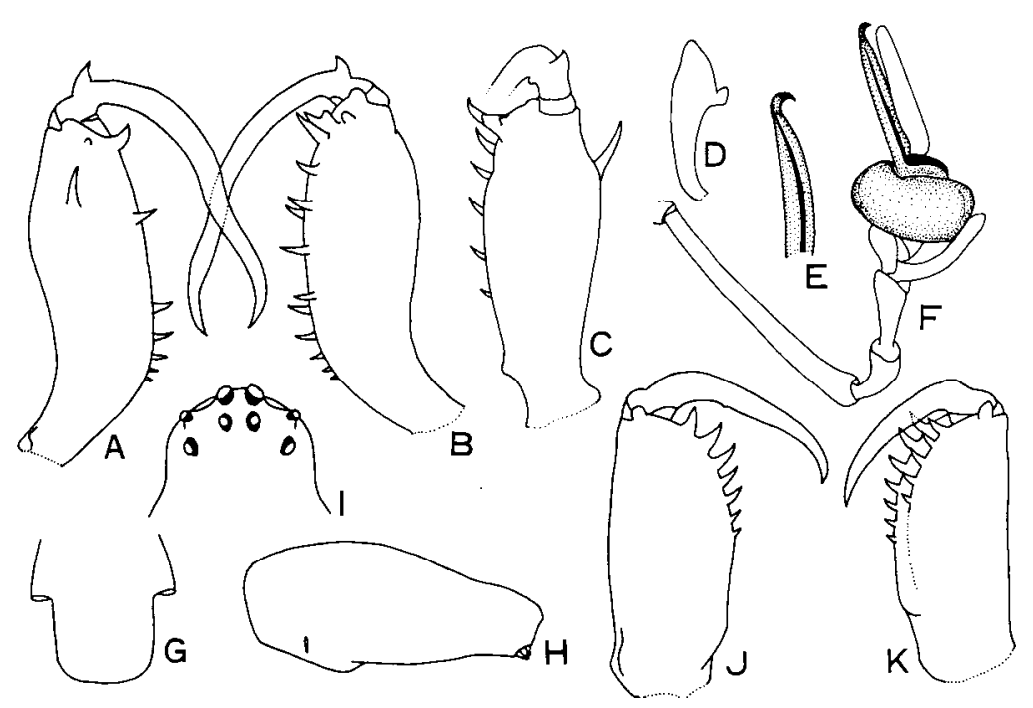

Fig. 5. Tetragnatha squamata Karsch. A: Left chelicera of male, upper view. B: Ditto, lower view. C : Ditto, lateral view. D : Paracymbium of male. E : Distal portion of conductor and embolus of male. F : Left palpus of male. G : Genital fold of female. $\mathrm{H}$ : Abdomen of female, lateral view. I : Eye group of female. J : Left chelicera of female, upper view. K : Ditto, lower view.

Table 5. Tetragnatha squamata Karsch. Relative lengths of total legs and femora.

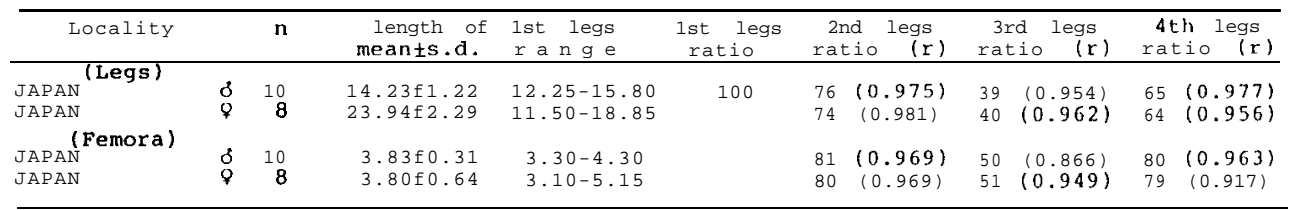

pointed at tip ; $(\mathrm{AXu})$ bluntly rounded at tip, slightly separated from $(\mathrm{Gu}) ;(\mathrm{Gu}),(\mathrm{U} 2)$ and (U3) subequal in size and spacing ; $(\mathrm{AXl})$ present, close to $(\mathrm{Gl}) ;(\mathrm{Gl})$ large, with a tubercle at the middle, (rsl) 4-5 in number ; fang with an outer cusp near base.

Legs. Leg formula 1. 2. 4. 3 ; all legs with spines, first femur with 5-6 spines ; relative lengths of legs as shown in Table 5.

Palpi. Paracymbium bluntly rounded at tip; tip of conductor hook-like and somewhat twisted as shown in Fig. 5, E and F.

Abdomen. Not so long, less than 3 times as long as broad.

Color in alcohol. Generally yellowish brown; abdomen covered with many yellowish silvery spangles; some specimens with reddish dorsal markings.

Female. Body length, exclusive of chelicerae 4.0-5.8 mm ; carapacial length 1.6$2.4 \mathrm{~mm}$, width 1.1-1.6 mm ; abdominal length 2.4-3.5 mm, width 1.1-1.4 mm ; cheliceral length $0.75-0.8 \mathrm{~mm}$.

Eyes. Nearly as in male.

Chelicerae. Basal segment slightly shorter than one-half of carapace ; without 
paticular features.

Legs. Nearly as in male, relative lengths of legs as shown in Table 5.

Abdomen. Not so long, less than 2.5 times as long as broad, somewhat swollen at the middle.

Color in alcohol. Similar to male ; abdominal marking absent.

Specimens examined : KOREA : 26, Kah-zan, Dalung, Gyongsangbug-Do, 19. VI. 1977, K. Yamagishi. TAIWAN :2 $^{7}, 1$ 우, Lishan, Taichung, 8-10. VI. 1980, H. Makihara ;1 $1 \sigma^{\nearrow}$, Baron, Taoyua, 20. V. 1980, H. Makihara. JAPAN : Many specimens of both sexes from Honshu, Shikoku, Kyushu and the Ryukyus.

Distribution : Japan, Taiwan and Korea.

\section{The rubriventris-group}

Diagnosis. Posterior row of eyes evidently narrower than anterior row; male chelicera as long as or longer than carapace.

Tetragnatha rubriventris, an Australasian species, does not occur is Asia.

Tetragnatha hasselti Thorell, 1890

(Fig. 6, Table 6)

Tetragnatha hasselti Thorell, 1890, Ann. Mus. Civ. Genova, $28: 217$; Merian, 1911, Zool. Jahrb Syst., 31 (2) : 185 ; Gravely, 1921, Rec. Ind. Mus. Calcutta, $22(4 ; 24): 428$.

Male. Body length, exclusive of chelicerae 8.2-9.7 mm ; carapacial length 2.4-2.9

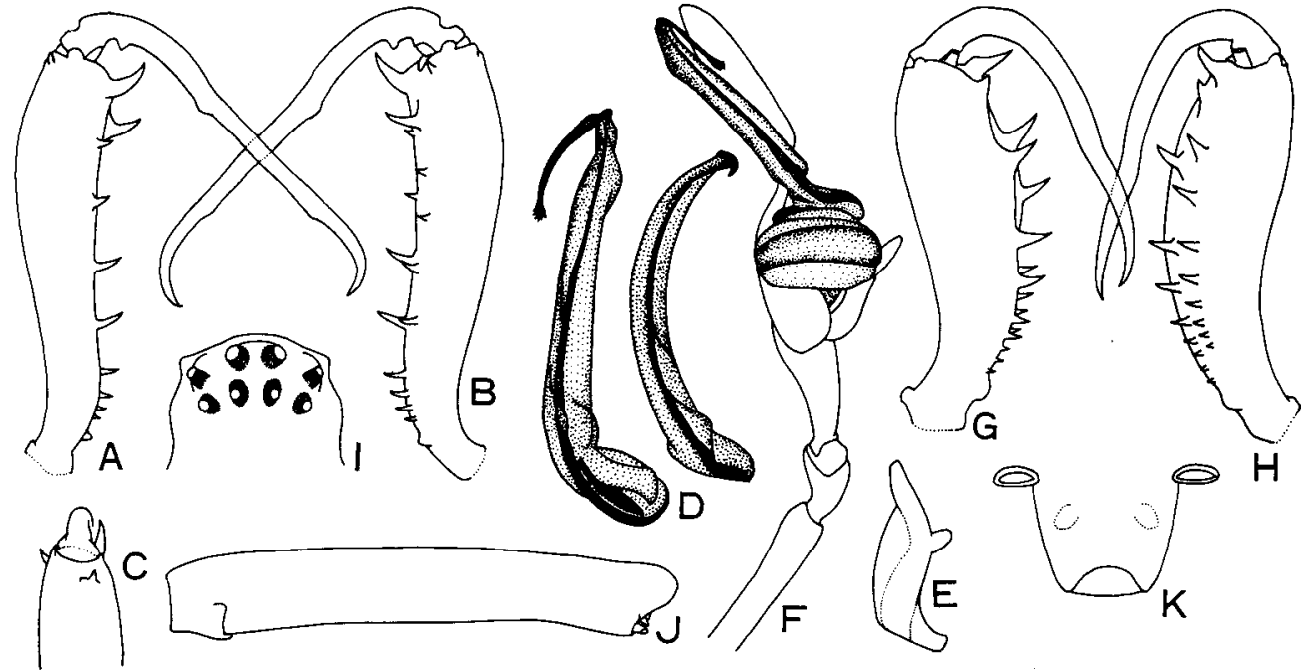

Fig. 6. Tetragnathahasselti Thorell. A : Left chelicera of male, upper view. B : Ditto, lower view. C : Ditto, lateral view. D : Conductor and embolus of male. E :Paracymbium of male. F : Left palpus of male. G : Left chelicera of female, upper view. H : Ditto, lower view. I: Eye group of male. J : Abdomen of male, lateral view. K: Genital fold of female. 


\begin{tabular}{|c|c|c|c|c|c|c|c|c|c|c|}
\hline Locality & & $n$ & $\begin{array}{l}\text { length of } \\
\text { meants.d. }\end{array}$ & $\begin{array}{r}\text { 1st legs } \\
\text { range }\end{array}$ & $\begin{array}{l}\text { 1st legs } \\
\text { ratio }\end{array}$ & $\begin{array}{r}2 \text { nd } \\
\text { rati }\end{array}$ & $\begin{array}{c}\text { legs } \\
0 \quad(\mathrm{r}) \\
\end{array}$ & $\begin{array}{l}3 \text { rd } \\
\text { ratio }\end{array}$ & $\begin{array}{l}\text { legs } \\
(\mathrm{r})\end{array}$ & $\begin{array}{l}\text { 4th legs } \\
\text { ratio ( } \text { ) }\end{array}$ \\
\hline $\begin{array}{l}\text { (Legs) } \\
\text { THAILAND }\end{array}$ & d & 4 & $32.10 f 1.70$ & $30.00-33.90$ & 100 & 61 & $(0.999)$ & 30 & $(0.973)$ & $55 \quad(0.985)$ \\
\hline THAILAND & 8 & 4 & $8.60 \pm 0.50$ & 8.00- 9.00 & & 69 & $(0.992)$ & 41 & $(0.966)$ & $(0.966)$ \\
\hline
\end{tabular}

$\mathrm{mm}$, width 1.2-1.5 mm ; abdominal length 5.6-6.9 mm, width 0.9-1.1 mm ; cheliceral length 3.0-3.6 mm.

Eyes. Anterior row of eyes occupying full width of head ; posterior row considerably narrower than anterior one ; viewed from above, anterior row somewhat strongly recurved, posterior row moderately recurved, so that lateral eyes slightly closer than median eyes.

Chelicerae. Long and slender, basal segment about 1.2 times as long as carapace ; (a) situated near apex, very small, not bifurcated at tip ; (Gu) longest, (U2) and (U3) smaller than (U4) ; (G1) small, (L2) somewhat long, (L3) and (L4) somewhat smaller than (L5); fang with two inner cusps.

Legs. Leg formula 1. 2. 4. 3 ; all legs with rather week spines, first femur with about 8-10 spines. relative lengths of legs as shown in Table 6.

Palpi. Paracymbium bluntly rounded at tip; both conductor and embolus long; tip of conductor variable in shape as shown in Fig. 6, D.

Color in alcohol. Legs, carapace and mouth parts light yellowish brown, sternum pale yellow ; basal half of abdomen somewhat reddish, apical half grayish and covered with yellowish silvery spangles dorsally.

Female. Body length, exclusive of chelicerae, $7.2 \mathrm{~mm}$; carapacial length $2.2 \mathrm{~mm}$, width $1.25 \mathrm{~mm}$; abdominal length $5.1 \mathrm{~mm}$, width $1.2 \mathrm{~mm}$; cheliceral length $2.0 \mathrm{~mm}$.

Eyes. Nearly as in male.

Chelicerae. Basal segment slightly shorter than carapace ; without (s) on outer side near apex ; $(\mathrm{Gu})$ shorter than (U2), (rsu) 7 in number ; $(\mathrm{Gl})$ somewhat large, (rsl) 8 in number ; fang without cusps.

Legs. Nearly as in male ; relative lengths of legs as shown in Table 6.

Abdomen. Similar to male ; genital fold as shown in Fig. 6, K.

Color in alcohol. Nearly as in male.

Specimens examined : BANGLADESH : 16, Mymensingh, 12. IV. 1987, Y. Hira-

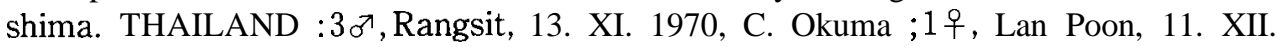
1985, T. Sasaki.

Distribution : Bangladesh (new record), Burma, Java, Celebes and Thailand (new record).

$$
\begin{aligned}
& \text { The striata-group } \\
& \text { (= The jaculator-group) }
\end{aligned}
$$

Diagnosis. Posterior row of eyes evidently narrower than anterior row of eyes ; cheliceral length shorter than carapace in both sexes ; lateral eyes more separated than median eyes ; distal end of abdomen slightly overhanging spinnerets.

Tetragnatha striata, a Euaropian species, does not occur in Asia. 
KEY TO THE SPECIES

1 Conductor with tip bifurcated ; paracymbium with tip broadened and rounded

- Conductor and paracymbium not as above

2 Conductor with tip narrow and straight 3

- Conductor not as above vermiformis

3 Male cheliceral fang with one inner cusp at about the middle virescens

Tetragnatha vermiformis Emerton, 1884

(Fig. 7, Table 7)

Tetragnatha vermiformis Emerton, 1884, Trans. Connect. Acad. Sci., $6: 333$; Okuma, 1983, Esakia, (20) : 77 .

Additional specimens : BAMGLADESH : 26, 1우, Central Bangladesh, VIII-IX. 1978, H. D. Catring. MALAYSIA :1 $\sigma^{7}$, Alor Sata, III. 1981, K. Umeya.

Distribution : Bangladesh (new record), India, Sri Lanka, Burma, Thailand, Malaysia (new record), China, Korea, Japan and U. S. A.

Note : This species has been known to occur widely in warm and tropical parts of the world and certainly inhabit near water. Body length : male 5.0-9.5 mm, female 6.5-10.5 mm.

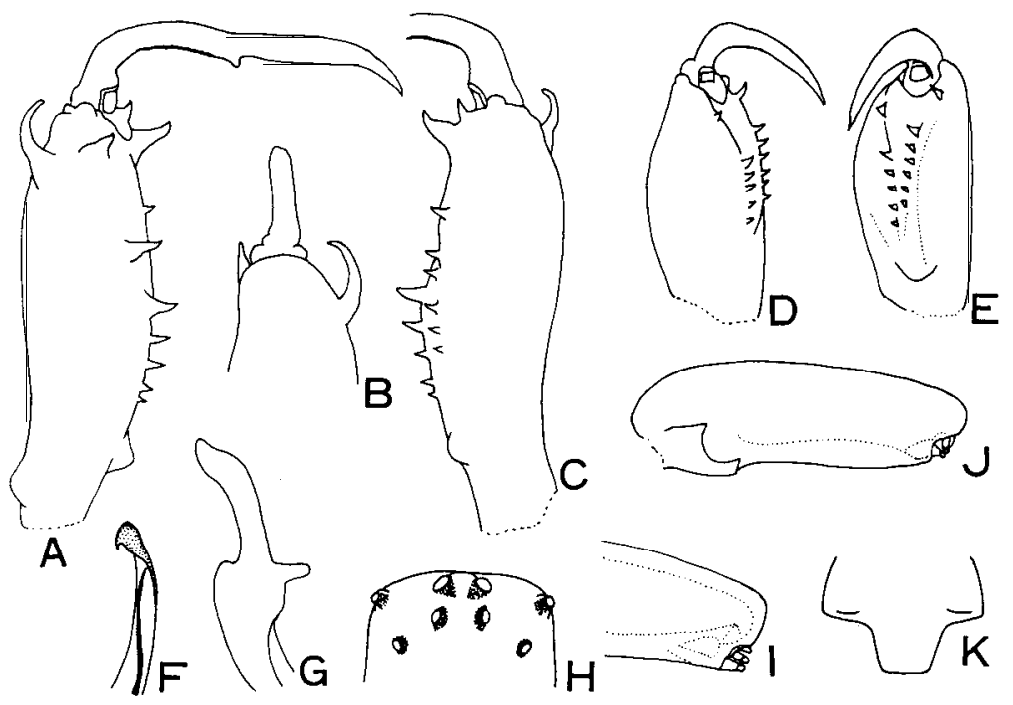

Fig. 7. Tetragnatha vermiformis Emerton. A : Left chelicera of male, upper view. B : Ditto, lateral view. C : Ditto, lower view. D : Left chelicera of female, upper view. E : Ditto, inner view. F : Distal portion of conductor and embolus of male. $G$ : Paracymbium of male. $\mathrm{H}$ : Eye group of male. I : Distal portion of Abdomen of male. $\mathrm{J}$ : Abdomen of female, lateral view. K : Genital fold of female. (After Okuma, 1983). 
Table 7. Tetragnatha vermiformis Emerton. Relative lengths of total legs and femora.

\begin{tabular}{|c|c|c|c|c|c|c|c|c|c|c|c|}
\hline \multicolumn{2}{|l|}{ Locality } & \multirow[t]{2}{*}{$\mathbf{n}$} & \multirow[t]{2}{*}{$\begin{array}{c}\text { length of } \\
\text { meants.d. }\end{array}$} & \multirow[t]{2}{*}{$\begin{array}{l}\text { 1st legs } \\
\mathrm{ran} \mathrm{ge}\end{array}$} & \multirow[t]{2}{*}{$\begin{array}{l}\text { 1st legs } \\
\text { ratio }\end{array}$} & \multicolumn{2}{|c|}{$\begin{array}{l}\text { 2nd legs } \\
\text { ratio (r) }\end{array}$} & \multicolumn{2}{|c|}{$\begin{array}{l}3 \text { rd legs } \\
\text { ratio ( } r \text { ) }\end{array}$} & \multicolumn{2}{|c|}{$\begin{array}{l}\text { 4th legs } \\
\text { ratio (r) }\end{array}$} \\
\hline (Legs) & & & & & & & & & & & \\
\hline Tokyo & $\xi$ & 5 & $19.21 i 3.44$ & $14.80-23.30$ & 100 & 70 & $(0.998)$ & 30 & $(0.995)$ & 64 & $(0.998)$ \\
\hline Tokushima & $\delta$ & 8 & $19.91 \pm 1.17$ & $18.15-21.75$ & & 68 & $(0.994)$ & 29 & $(0.869)$ & 63 & $(0.963)$ \\
\hline Fukuoka & $\delta$ & 2 & $22.15 f 4.53$ & $18.95-25.35$ & & 68 & & 29 & & 64 & \\
\hline Tsushima & $\delta$ & 1 & 21.65 & & & 70 & & 31 & & 65 & \\
\hline Tokyo & \% & 4 & $17.00 \pm 1.20$ & $15.40-17.90$ & & 69 & $(0.991)$ & 32 & $(0.995)$ & 67 & $(0.996)$ \\
\hline Tokushima & $q$ & 5 & $15.8 \mathrm{Gf} 0.77$ & $14.65-16.75$ & & 68 & $(0.978)$ & 31 & $(0.988)$ & 66 & $(0.988)$ \\
\hline Fukuoka & \& & 6 & $16.46 \pm 1.73$ & $13.55-18.85$ & & 69 & $(0.998)$ & 31 & $(0.987)$ & 67 & $(0.985)$ \\
\hline Tsushima & $q$ & 1 & 17.95 & & & 71 & & 31 & & 68 & \\
\hline $\begin{array}{l}\text { KOREA } \\
\text { (Femora) }\end{array}$ & \& & 2 & 17.80 & $15.00-20.60$ & & 71 & & 32 & & 66 & \\
\hline Tokyo & of & 5 & $5.42 f 1.01$ & $4.20-6.60$ & & 76 & $(0.997)$ & 35 & $(0.997)$ & 75 & $(0.997)$ \\
\hline Tokushima & $\delta$ & 8 & $5.61 \pm 0.34$ & $5.15-6.10$ & & 74 & 10.9941 & 35 & $(0.923)$ & 74 & $(0.966)$ \\
\hline Fukuoka & o & 2 & $6.33 \mathrm{f} 1.10$ & $5.55-7.10$ & & 74 & & 34 & & 76 & \\
\hline Tsushima Is. & 8 & 1 & 6.30 & & & 69 & & & & & \\
\hline Tokyo & $Q$ & 4 & $4.90 f 0.29$ & $4.50-5.20$ & & 74 & $(0.958)$ & 3436 & $(0.996)$ & 7579 & $(0.999)$ \\
\hline Tokuahim & $\mathrm{Q}$ & 5 & $4.52 \pm 0.14$ & $4.35-4.70$ & & 74 & $(0.956)$ & 37 & $(0.786)$ & 77 & $(0.931)$ \\
\hline Fukuoka & 9 & 6 & $4.72 f 0.50$ & $3.90-5.40$ & & 74 & $(0.995)$ & 36 & $(0.957)$ & 80 & $(0.981)$ \\
\hline Tsushima Is. & $q$ & 1 & 5.25 & & & 76 & & 35 & & 80 & \\
\hline KOREA & $\%$ & 2 & 5.05 & $4.30-5.80$ & & 76 & & 37 & & 78 & \\
\hline
\end{tabular}

Tetragnatha laqueata L. Koch, 1871

(Fig. 8, Table 8)

Tetragnatha laqueata L. Koch, 1871, Die Arachniden Australiens, 1 : 190 ; Okuma, 1980, Esakia, (15) :

75.

Distribution : Samoa Is., Societe Is. and Ogasawara Is.

Note : The spider of this species usualy inhabits on the tree, and the body is brilliant light green in color in life. Body length : male 5.2-6.6 mm, female 6.2-6.5 mm.

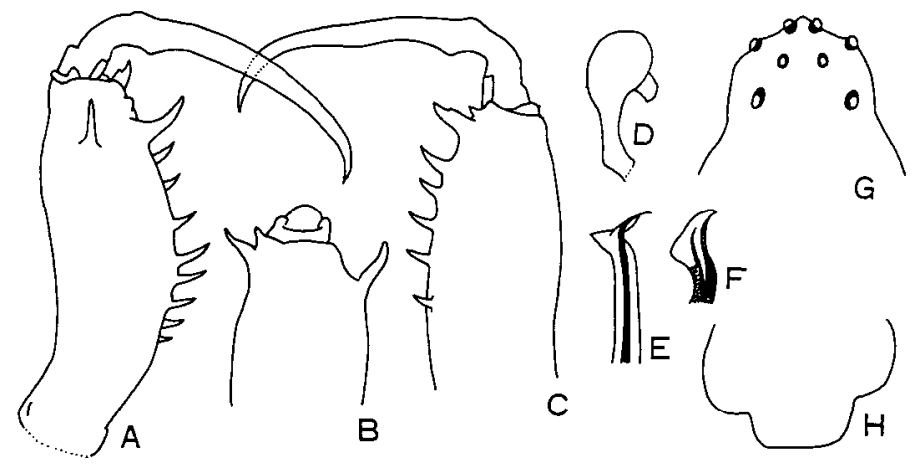

Fig. 8. Tetragnatha laqueata L. Koch. A: Left chelicera of male, upper view. B : Ditto, lateral view. C : Ditto, lower view. D : Paracymbium of male. E and F : Distal portion of conductor and embolus of male. G : Eye group of female. $\mathrm{H}$ : Genital fold of female. (After Okuma, 1980).

Table 8. Tetragnatha laqueata L. Koch. Relative lengths of total legs and femora.

\begin{tabular}{|c|c|c|c|c|c|c|c|c|}
\hline Locality & & $\mathbf{n}$ & $\begin{array}{l}\text { length of } \\
\text { meants.d. }\end{array}$ & $\begin{array}{c}\text { 1st legs } \\
\text { range }\end{array}$ & $\begin{array}{l}\text { 1st legs } \\
\text { ratio }\end{array}$ & $\begin{array}{l}\text { 2nd legs } \\
\text { ratio (r) }\end{array}$ & $\begin{array}{cc}\text { 3rd legs } \\
\text { ratio (r) }\end{array}$ & $\begin{array}{l}\text { 4th legs } \\
\text { ratio }(\mathrm{r})\end{array}$ \\
\hline (Legs) & & & & & & & & \\
\hline Ogasawara Is. & d & 17 & $15.14 \pm 1.34$ & $11.05-16.50$ & 100 & $(0.997)$ & $38 .(0.982)$ & $(0.993)$ \\
\hline $\begin{array}{c}\text { Ogasawara Is. } \\
\text { (Femora) }\end{array}$ & $Q$ & 6 & 12.4450 .53 & $11.85-13.25$ & & $(0.980)$ & $(0.921)$ & 7210.9 \\
\hline $\begin{array}{l}\text { Ogasawara IS. } \\
\text { Ogasawara Is. }\end{array}$ & $\stackrel{8}{Q}$ & $\begin{array}{r}17 \\
6\end{array}$ & $\begin{array}{l}4.09 \pm 0.23 \\
3.48 \pm 0.16\end{array}$ & $\begin{array}{l}3.50-4.45 \\
3.30-\quad 3.70\end{array}$ & & $\begin{array}{lc}80 & (0.979) \\
70 & (0.963)\end{array}$ & $\begin{array}{ll}50 & (0.951) \\
50 & (0.814)\end{array}$ & $\begin{array}{ll}86 & (0.9791 \\
88 & (0.974)\end{array}$ \\
\hline
\end{tabular}


Tetragnatha virescens Okuma, 1979

(Fig. 9, Table 9)

Tetragnatha virescens Okuma, 1979, Esakia, (14):73.

Additional specimens : MALAYSIA :3 ๙ $^{7}, 2$ 우,Alor Sata, III. 1981, K. Umeya.

Distribution : Sri Lanka, Thailand, Malaysia, Indonesia and Philippines.

Note : This species is common in paddy fields of Tropical Asia, and the body is light green in color similar to the leaf of rice plant in life. Body length: male 5.5$8.0 \mathrm{~mm}$. female $6.5-8.5 \mathrm{~mm}$.

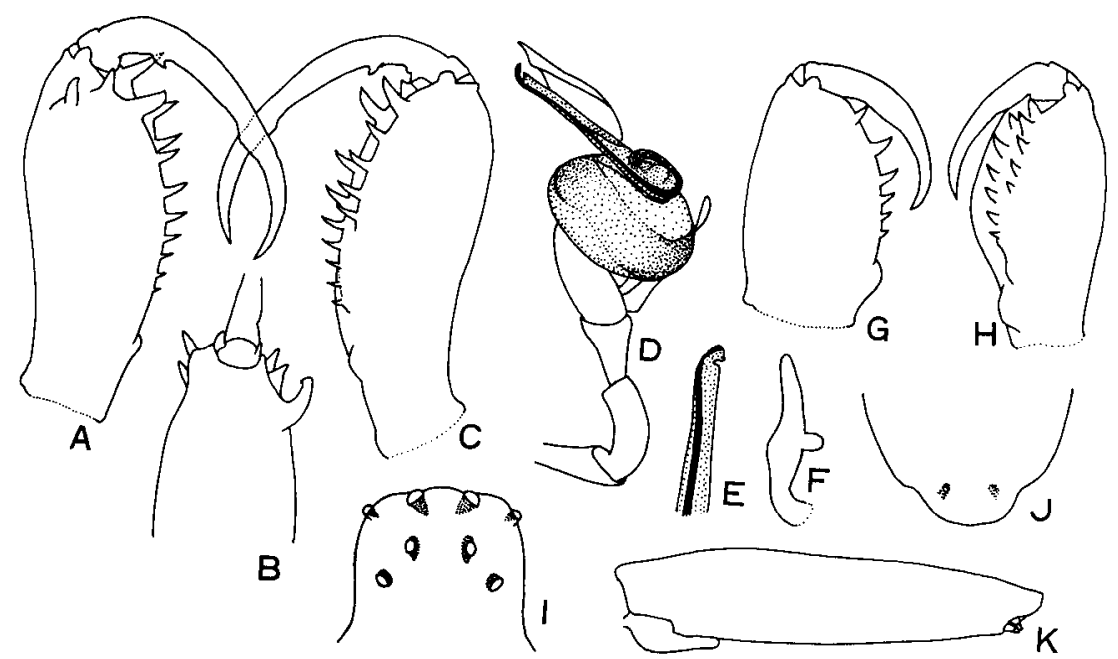

Fig. 9. Tetragnatha virescens Okuma. A : Left chelicera of male, upper view. B : Ditto, lateral view. C : Ditto, lower view. D : Left palpus of male. E : Distal portion of conductor and embolus of male. F: Paracymbium of male. G: Left chelicera of female, upper view. H : Ditto, lower view. I : Eye group of male. J : Genital fold of female. $\mathrm{K}$ : Abdomen of female, lateral view.

\begin{tabular}{|c|c|c|c|c|c|c|c|c|c|}
\hline Locality & & $n$ & $\begin{array}{l}\text { length of } \\
\text { meants.d. }\end{array}$ & $\begin{array}{l}\text { 1st legs } \\
r \text { a } \mathrm{ng} e\end{array}$ & $\begin{array}{l}\text { 1st legs } \\
\text { ratio }\end{array}$ & $\begin{array}{l}2 \text { nd } \\
\text { ratio }\end{array}$ & $\begin{array}{l}\text { legs } \\
\text { (r) }\end{array}$ & $\begin{array}{l}3 \text { rd legs } \\
\text { ratio (r) }\end{array}$ & $\begin{array}{l}\text { 4th legs } \\
\text { ratio (r) }\end{array}$ \\
\hline (Legs) & & & & & & & & & \\
\hline THAI LAND & $\delta$ & 20 & $17.50 \mathrm{f} 1.23$ & $14.95-20.85$ & 100 & 68 & $(0.994)$ & $(0.884)$ & $65(0.980)$ \\
\hline $\begin{array}{l}\text { THAI LAND } \\
\text { (Femora) }\end{array}$ & $Q$ & 20 & $15.54 \mathrm{f} 1.27$ & $13.53-18.20$ & & 671 & 0) & $31(0.965)$ & 6710 \\
\hline TIIAILAND & d & 20 & $5.06 f 0.36$ & $4.25-6.00$ & & 73 & $(0.984)$ & $36(0.939)$ & $(0.955)$ \\
\hline TIIA I LAND & $Q$ & 20 & $4.59 f 0.36$ & $3.95-5.30$ & & 721 & $0.984)$ & $36(0.939)$ & $\begin{array}{ll}78 & (0.975)\end{array}$ \\
\hline
\end{tabular}

Tetragnatha jaculator Tullgren, 1910

(Fig. 10, Table 10)

Tetragnatha jaculator Tullgren, 1910, Aran. in: Sjöstedt Kilimand. Exped., 3: 150 ; Okuma, 1984, Esakia, (22) : 87; Okuma, 1987, Esakia, (25) : 55. 


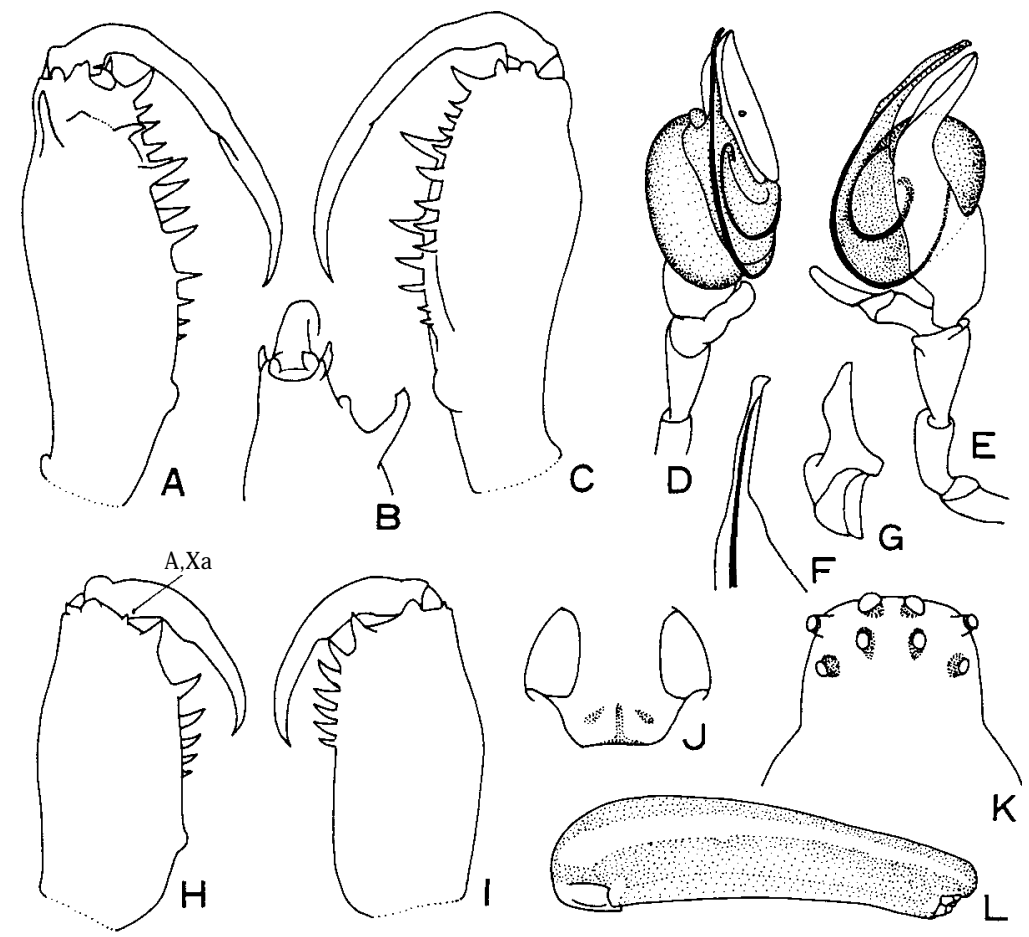

Fig. 10. Tetragnatha jaculator Tullgren. A : Left chelicera of male, upper view. B : Ditto, lateral view. C : Ditto lower view. D and E : Left palpus of male. F : Conductor and embolus of male. G: Paracymbium of male. H : Left chelicera of female, upper view. I : Ditto, lower view. J : Genital fold of female. K : Eye group of female. L : Abdomen of female, lateral view. (After Okuma, 1987).

\begin{tabular}{|c|c|c|c|c|c|c|c|c|c|}
\hline Locality & & $\mathbf{n}$ & $\begin{array}{l}\text { length of } \\
\text { meants.d. }\end{array}$ & $\begin{array}{c}\text { 1st legs } \\
\mathrm{r} \text { a } \mathrm{n} \mathrm{g} \mathrm{e}\end{array}$ & $\begin{array}{l}\text { 1st legs } \\
\text { ratio }\end{array}$ & $\begin{array}{l}\text { 2nd legs } \\
\text { ratio (r) }\end{array}$ & 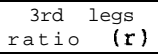 & $\begin{array}{c}4 \text { th } \\
\text { ratio }\end{array}$ & $\begin{array}{r}\operatorname{legs} \\
(x)\end{array}$ \\
\hline $\begin{array}{l}\text { (Legs) } \\
\text { THAILAND } \\
\text { PHILIPPINES }\end{array}$ & $\begin{array}{l}8 \\
9\end{array}$ & $\begin{array}{l}3 \\
1\end{array}$ & $\begin{array}{c}14.92 \mathrm{f} 1.10 \\
19.13\end{array}$ & $14.10-16.05$ & 100 & $(0.991)$ & $\begin{array}{ll}28 & (0.963) \\
28 & \end{array}$ & $\begin{array}{l}601 \\
62\end{array}$ & 1 \\
\hline $\begin{array}{l}\text { THAI (Femora) } \\
\text { PHILIPP INES }\end{array}$ & $\begin{array}{l}8 \\
9\end{array}$ & $\begin{array}{l}3 \\
1\end{array}$ & $\begin{array}{c}4.25 f 0.23 \\
5.55\end{array}$ & $4.05-\quad 4.50$ & & $\begin{array}{ll}70 & (0.996) \\
67 & \end{array}$ & $\begin{array}{ll}35 & (0.954) \\
33 & \end{array}$ & $\begin{array}{l}71 \quad 10 \\
75\end{array}$ & .9821 \\
\hline
\end{tabular}

Distribution : Africa, SE Asia and New Guinea.

Note : This species mainly inhabits on grass near water. This specie is related to T. vermiformis but is separable from the latter by the shape of the male palp as shown in Fig. 10, D and E. Body length: male 4.5-8.1 mm, female 6.1-9.7 mm.

\section{The cylindrica-group}

Diagnosis. Anterior and posterior rows of eyes equal or subequal in width ; abdomen very long, about 6-10 times as long as broad, tail absent. 
Tetragnatha cylindrica, an Australasian species, does not occur in Asia.

\section{KEY TO THE SPECIES}

1 Paracymbium slender, with tip pointed ; distal end of conductor unique

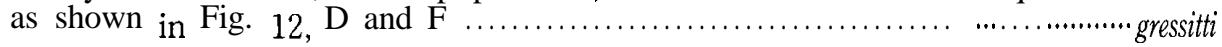

- Paracymbium not slender 2

2 Paracymbium rather broad, with tip pointed ; conductor simple $\cdots \cdot \cdot$ chauliodus

- Paracymbium broad, with tip bifurcated ; distal end of conductor unique as shown in Fig. 13, D and E

geniculata

\section{Tetragnatha chauliodus (Thorell, 1980)}

(Fig. 11, Table 11)

Limoxere chauliodus Thorell, 1890, Ann. Mus. Civ. Genova, 30 : 292.

Tetragnatha chauliodus : Gravely, 1921, Rec. Ind. Mus., 22 : 425 ; Okuma, 1987, Esakia, (25) : 62.

Tetragnatha sp. Okuma, 1970, Mushi, $44: 74$; Okuma, 1973, Mushi $47: 8$.

Male. Body length, exclusive of chelicera $6.0-10.0 \mathrm{~mm}$; carapacial length 1.8-2.5 $\mathrm{mm}$, width $0.9-1.0 \mathrm{~mm}$; abdominal length $4.0-7.5 \mathrm{~mm}$, width $0.5-1.0 \mathrm{~mm}$; cheliceral length $1.0-1.7 \mathrm{~mm}$.

Eyes. Anterior row of eyes occupying full width of head, posterior row about as wide as anterior one; viewed from above, two rows nearly parallel and moderately recurved.

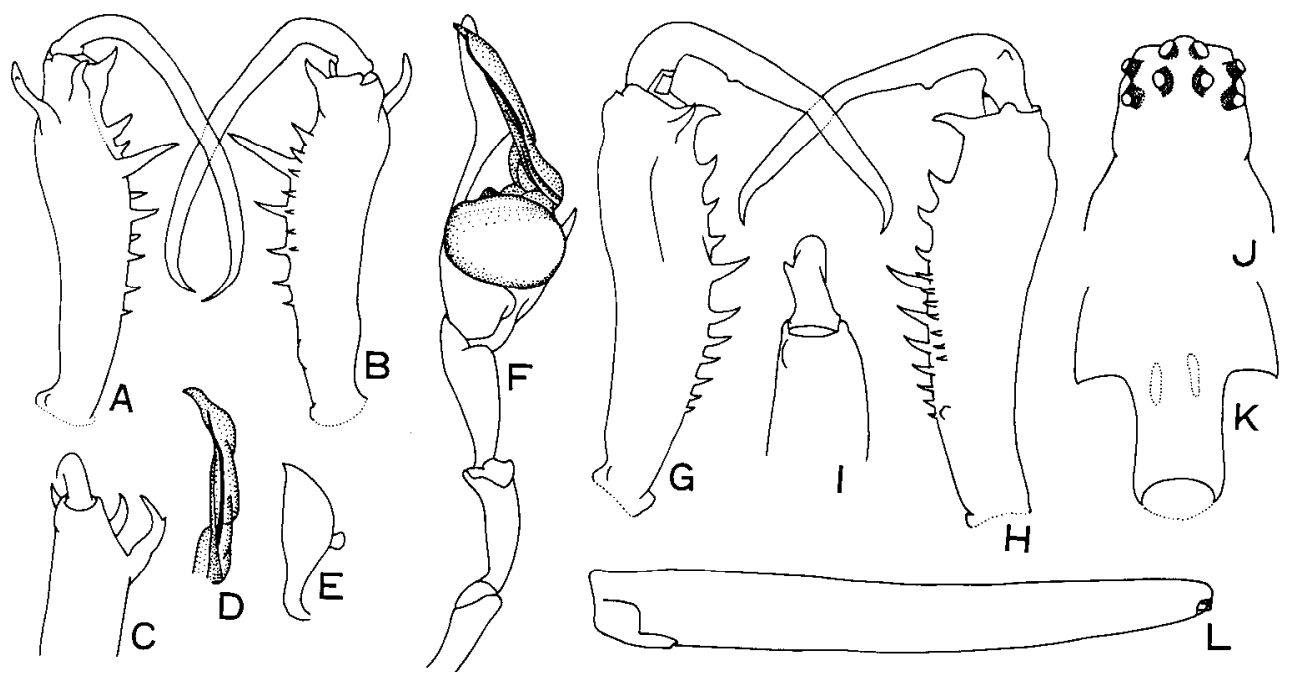

Fig. 11. Tetragnatha chauliodus (Thorell). A : Left chelicera of male, upper view. B : Ditto, lower view. C : Ditto, lateral view. D : Distal portion of conductor and embolus of male. E : Paracymbium of male. F : Left palpus of male. G : Left chelicera of female, upper view. H : Ditto, lower view. I : Ditto, lateral view. J : Eye group of female. K: Genital fold of female. L: Abdomen of female, lateral view. 
Table 11. Tetragnatha chauliodus (Thorel1). Relative lengths of total legs and femora.

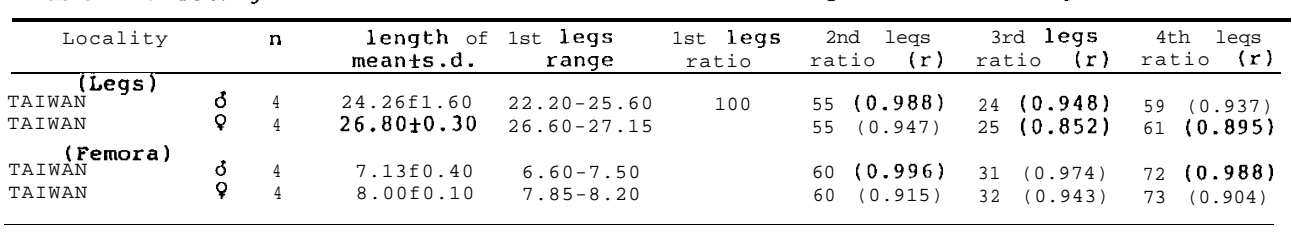

Chelicerae. Basal segment about 0.6 times as long as carapace ; (a) bifid at tip, (AXu) and $(\mathrm{Gu})$ absent, (sl) somewaht curved, directed forward, (T) large, (rsu) about 4 in number; (Gl) directed forward, (rsl) about 7 in number ; fang unarmed.

Legs. Leg formula 1. 4. 2. 3 ; all legs with only a few spines, first femur with 12 spines; relative lengths of legs as shown in Table 11.

Palpi Paracymbium broad at the middle, not bifurcated at tip; conductor of embolus simple, gently twisted as shown in Fig. 11, D and F.

Abdomen. Elongate, about 7-8 times as long as broad, not extended posteriorly to spinnerets.

Color in alcohol. Generally light brown ; abdomen light gray, dorsum with dusky spots on lateral sides.

Female. Body length, exclusive of chelicerae $8.4-12.0 \mathrm{~mm}$; carapacial length 2.4$2.6 \mathrm{~mm}$, width $1.1-1.2 \mathrm{~mm}$; abdominal length $6.0-9.5 \mathrm{~mm}$, width $0.9-1.0 \mathrm{~mm}$; cheliceral length $1.7-1.8 \mathrm{~mm}$.

Eyes. Nearly as in male.

Chelicerae. Basal segment about 0.7 times as long as carapace ; $(\mathrm{Gu})$ and $(\mathrm{T})$ widely separated, (rsu) about 6 in number ; $(\mathrm{Gl})$ present, (rsl) about 10 in number ; fang with (EX) near base, and an additional inner tooth at about $1 / 3$ from base ; this additional tooth very variable in size, generally very long in the specimens from Singapore and New Guinea, short and small in the specimens from Taiwan and intermediate in those from Philippines.

Legs. Leg formula 1. 4. 2. 3 ; all legs with a few spines, first femur with 1-3 spines ; relative lengths of legs as shown in Table 11.

Abdomen. Elongate, about 6.5-9.5 times as long as broad, not extended posteriorly to spinnerets ; genital fold as shown in Fig. 11, K.

Color in alcohol. Similar to male.

Specimens examined : SINGAPORE : 1 우, Uln Sembawang, 5. XII. 1976, Joseph Koh. PHILIPPINES : 1 早, Luzon, 28. VII. 1985, Y. Nishikawa (NSMT-AR. 1126). TAIWAN : $20^{7}, 1$ 우, Urai, Taipei Hsien, 14. IV 1981, K. Ohara ; 1 우, Changlotsun, 16. VI. 1976, H. Makihara ;1우, Haianshan, 2. VI. 1980, H. Makihara ;1우. Hungyehwenchuan, 13. VI. 1976, H. Makihara.

Distribution : Burma, Thailand, Malaysia, Singapore, New Guinea, Philippines (new record) and Taiwan.

Tetragnatha gressitti Okuma, 1988

(Fig. 12, Table 12)

Tetragnatha gressitti Okuma, 1988, Esakia, (26) : 75 .

Distribution : Borneo. 


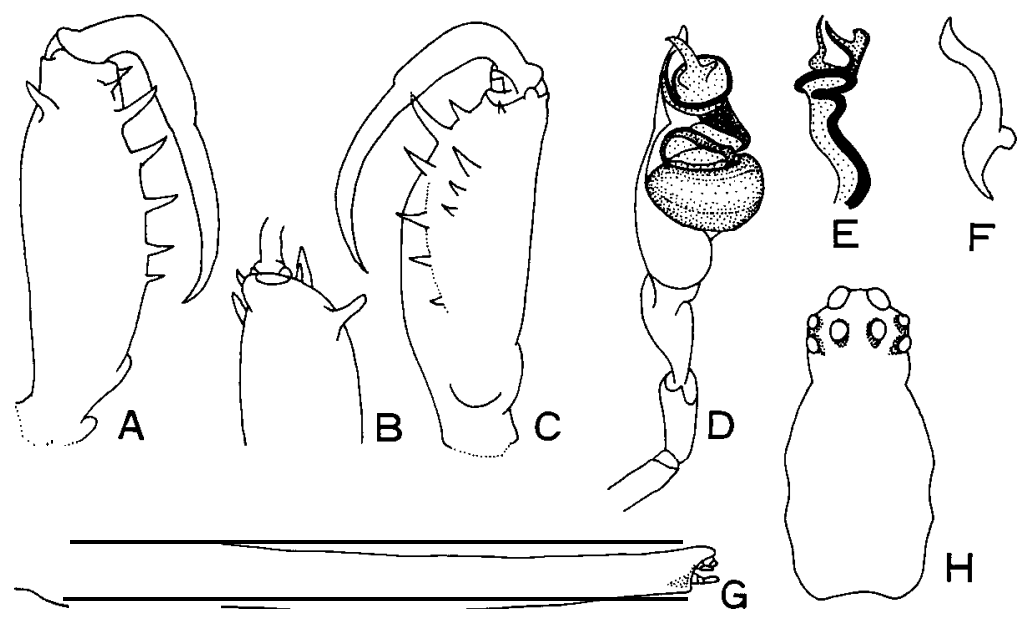

Fig. 12. Tetragnatha gressitti Okuma. A : Left chelicera of male, upper view. B: Ditto, lateral view. C : Ditto, lower inner view. D : Left palpus of male. E : Conductor and embolus of male. F : Paracymbium of male. G : Abdomen of male, lateral view. $\mathrm{H}$ : Carapace of male, upper view. (After Okuma, 1988).

Table 12. Tetragnatha gressitti Okuma. Relative lengths of total legs and femora.

\begin{tabular}{|c|c|c|c|c|c|c|c|c|}
\hline Locality & & $\mathbf{n}$ & $\begin{array}{l}\text { length of } \\
\text { meants.d. }\end{array}$ & $\begin{array}{l}\text { 1st legs } \\
\text { range }\end{array}$ & $\begin{array}{l}\text { 1st legs } \\
\text { ratio }\end{array}$ & $\begin{array}{l}\text { 2nd legs } \\
\text { ratio ( } \mathrm{x} \text { ) }\end{array}$ & $\begin{array}{l}\text { 3rd legs } \\
\text { ratio ( } \mathrm{r} \text { ) }\end{array}$ & $\begin{array}{l}\text { 4th legs } \\
\text { ratio (r) }\end{array}$ \\
\hline $\begin{array}{l}\text { (Legs) } \\
\text { BORNEO } \\
\text { (Femora) }\end{array}$ & $\delta$ & 2 & 17.25 & $15.90-18.60$ & 100 & 54 & 24 & 59 \\
\hline BOENEO & 3 & 2 & 5.33 & $4.95-5.70$ & & 57 & 29 & 68 \\
\hline
\end{tabular}

Note : This species is related to T. biseriata Thorell from New Guinea, Aru I. and Australia, but is easily distinguished from the latter by the characteristic the male palpal conductor and paracymbium as shown in Fig. 12, D and E. Body length : male 5.5-6.0 mm.

\section{Tetragnatha geniculata Karsch, 1891}

(Fig. 13, Table 13)

Tetragnatha geniculata Karsch, 1891, Berlin. Ent. Zeitschr., 36 : 286 ; Thorell, 1895, Descr.Catal. Spid. Burma : 140 ; Pocock, 1900, Faun. Brit. Ind. Arachn. : 215 ; Gravely, 1921, Rec. Ind. Mus. Calcutta, $22(4 ; 24): 426,441$.

Male. Body length, exclusive of chelicerae, $9.5 \mathrm{~mm}$; carapacial length $2.8 \mathrm{~mm}$, width $1.2 \mathrm{~mm}$; abdominal length $6.8 \mathrm{~mm}$, width $0.9 \mathrm{~mm}$; cheliceral length $2.5 \mathrm{~mm}$.

Eyes. Anterior row of eyes occupying full width of head ; posterior row of eyes slightly wider than anterior one ; viewed from above, anterior row somewhat strongly recurved, posterior row moderately recurved, so that lateral eyes closer than median eyes.

Chelicerae. Basal segment about 0.9 times as long as carapace ; (a) bifurcated at tip ; $(\mathrm{AXu})$ present, $(\mathrm{Gu})$ somewhat large, $(\mathrm{T})$ not so large, $(\mathrm{T})$ and $(\mathrm{U} 3)$ nearly equal in 

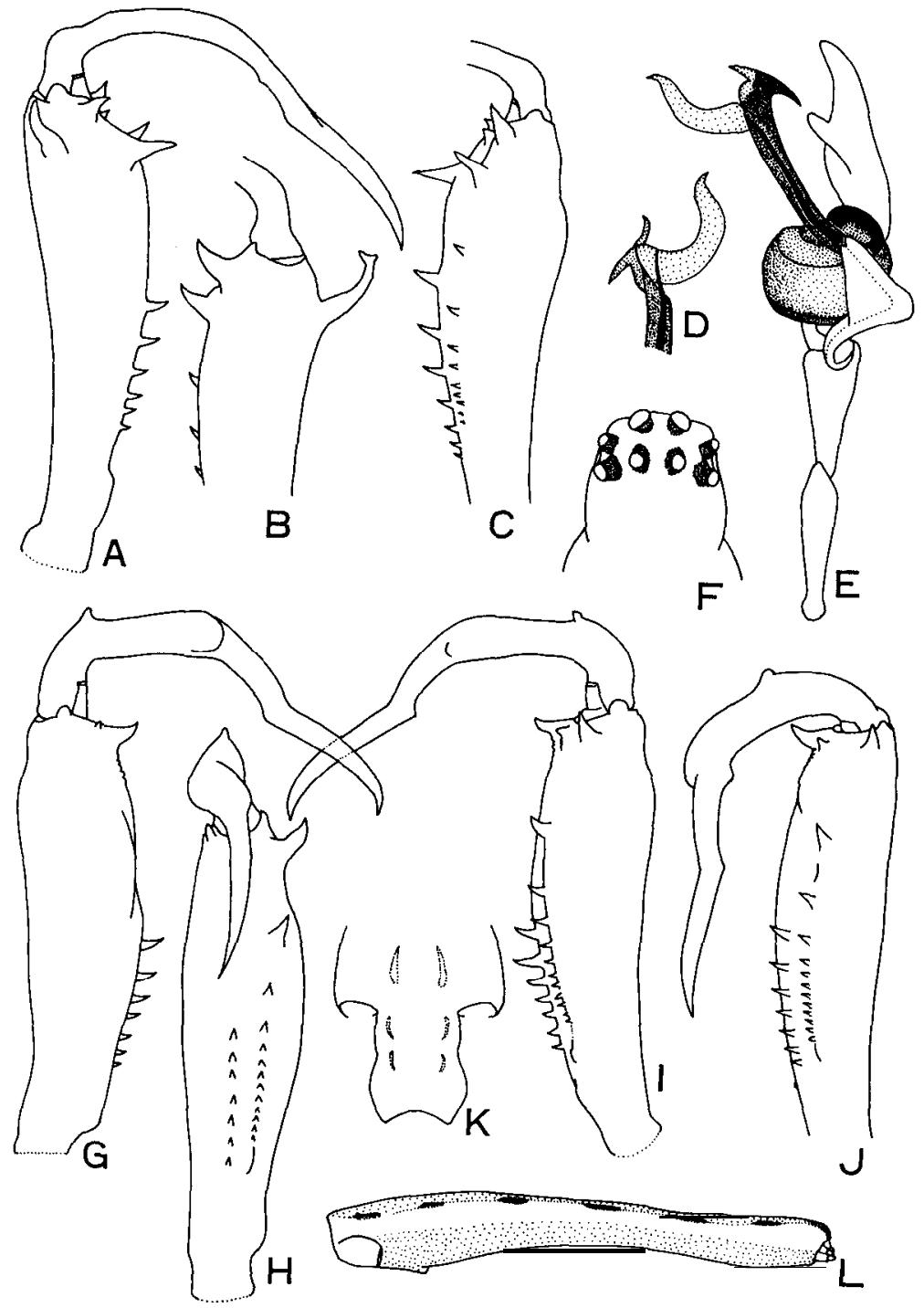

Fig. 13. Tetragnatha geniculata Karsch. A: Left chelicera of male, upper view. B: Ditto, lateral view. C : Ditto, lower view. D : Distal portion of conductor and embolus of male. E : Left palpus of male. F : Eye group of female. G : Left chelicera of female, upper view. H : Ditto, inner view. I : Ditto, lower view. J : Ditto, lower inner view. K : Genital fold of female. L : Abdomen of female, lateral view.

size, (rsu) 6-7 in number ; (Gl) and (L2) somewhat large, nearly equal in size, (rsl) 9 in number ; an additional tubercle present inside of fang furrow on distal portion ; fang long, armed with two inner cusps at about the middle.

Legs. Leg formula 1. 4. 2. 3; all legs with many spines, first femur with 11-12 


\begin{tabular}{|c|c|c|c|c|c|c|c|c|c|c|c|}
\hline Locality & & $n$ & $\begin{array}{l}\text { length of } \\
\text { meants.d. }\end{array}$ & $\begin{array}{c}\text { 1st legs } \\
\text { range }\end{array}$ & $\begin{array}{l}\text { 1st legs } \\
\text { ratio }\end{array}$ & $\begin{array}{l}\text { 2nd } \\
\text { ratio }\end{array}$ & $\begin{array}{l}\operatorname{legs} \\
\text { (r) }\end{array}$ & $\begin{array}{c}3 \text { rd } \\
\text { ratio }\end{array}$ & $\begin{array}{l}\text { legs } \\
\text { (r) }\end{array}$ & $\begin{array}{c}\text { 4th } \\
\text { ratio }\end{array}$ & $\begin{array}{l}\text { legs } \\
\text { (r) }\end{array}$ \\
\hline CHINA (Legs) & $\delta$ & 1 & 30.73 & & 100 & 55 & & 25 & & 56 & \\
\hline CHINA & $\mathrm{v}$ & 1 & 28.80 & & & 55 & & 26 & & 57 & \\
\hline THAILAND & $Q$ & 1 & 36.70 & & & 54 & & 26 & & 58 & \\
\hline $\operatorname{CIITN} \hat{\lambda}^{(\text {Femora) }}$ & o & 1 & 9.10 & & & 64 & & 32 & & 67 & \\
\hline $\mathrm{CHINA}$ & $\mathrm{v}$ & 1 & 8.50 & & & 60 & & 34 & & 68 & \\
\hline THAILAND & \% & 1 & 10.90 & & & 61 & & 33 & & 69 & \\
\hline
\end{tabular}

spines ; relative lengths of legs as shown in Table 13.

Palpi. Paracymbium with a distal notch ; conductor unique as shown in Fig. 13, $\mathrm{D}$ and $\mathrm{E}$.

Abdomen. Very long, about 7 times as long as broad, not extended posteriorly to spinnerets.

Color in alcohol. Chelicerae, carapace and legs light brown; fangs, maxillae, labium and sternum somewhat dark brown; abdomen somewhat pale brown, with pale blackish longitudinal lines and several dots dorso-laterally, grayish brown ventrally.

Female. Body length, exclusive of chericerae $11.8 \mathrm{~mm}$, carapacial length 2.7-3.1 $\mathrm{mm}$, width 1.2-1.4 mm; abdominal length $8.7-9.1 \mathrm{~mm}$, width $1.3-1.4 \mathrm{~mm}$; cheliceral length 2.4-2.7 mm.

Chelicerae. Basal segment about 0.9 times as long as carapace ; $(\mathrm{AXu})$ present, very small, $(\mathrm{Gu})$ and (U2) neary equal in size, (U2) widely separated from (Gu), (rsu) 6 in number ; $(\mathrm{Gl})$ present, ( $\mathrm{rsl}) 12$ in number ; an additional tubercle present inside of fang furrow on distal portion ; fang strongly geniculate, armed with blunt (EX) on outer margin near base.

Legs. Nearly as in male ; relative lengths of legs as shown in Table 13.

Abdomen. Long, about 6.5 times as long as broad, not extended posteriorly to spinnerets; genital fold as shown in Fig. 13, K.

Color in alcohol. Similar to male.

Specimen examined : THAILAND : 1 우, Khao Yai National Park, 20. IX. 1985, T. Sasaki.

Distribution : Sri Lanka, India, Burma and Thailand (new record).

\section{The lauta-group}

Diagnosis. Posterior row of eyes slightly narrower than anterior row of eyes, lateral eyes closer than median eyes ; all legs without spines; generally weak and glossy surface.

Tetragnatha lauta Yaginuma, 1959

(Fig. 14 and 15, Table 14)

Tetragnatha lauta Yaginuma, 1959, Bull. Osaka Mus. nat Hist., $11: 11$; Yaginuma, 1960, Spiders of Japan in Colour : 73 ; Yaginuma, 1986, Spiders of Japan in Color, New Edition : 131.

Male. Body length, exclusive of chelicerae 3.7-4.7 mm ; carapacial length 1.3-1.5 $\mathrm{mm}$, width 0.7-1.0 $\mathrm{mm}$; abdominal length $2.4-3.2 \mathrm{~mm}$, width $0.7-0.9 \mathrm{~mm}$; cheliceral length $0.85-1.1 \mathrm{~mm}$. 


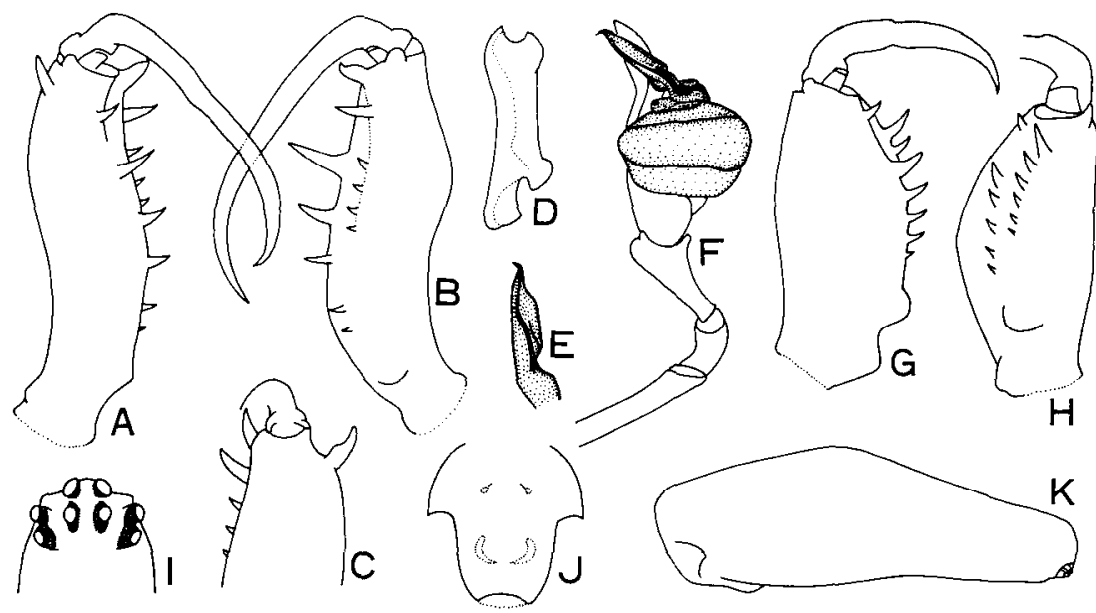

Fig. 14. Tetragnatha lauta Yaginuma. A: Left chelicera of male, upper view. B: Ditto, lower view. C : Ditto, lateral view. D : Paracymbium of male. E : Distal portion of conductor and embolus of male. F : Left palpus of male. G : Left chelicera of female, upper view. H : Ditto, lower inner view. I : Eye group of male. J : Genital fold of female. $\mathrm{K}:$ Abdomen of female.

Table 14. Tetragnatha lauta Yaginuma. Relative lengths of total legs and femora.

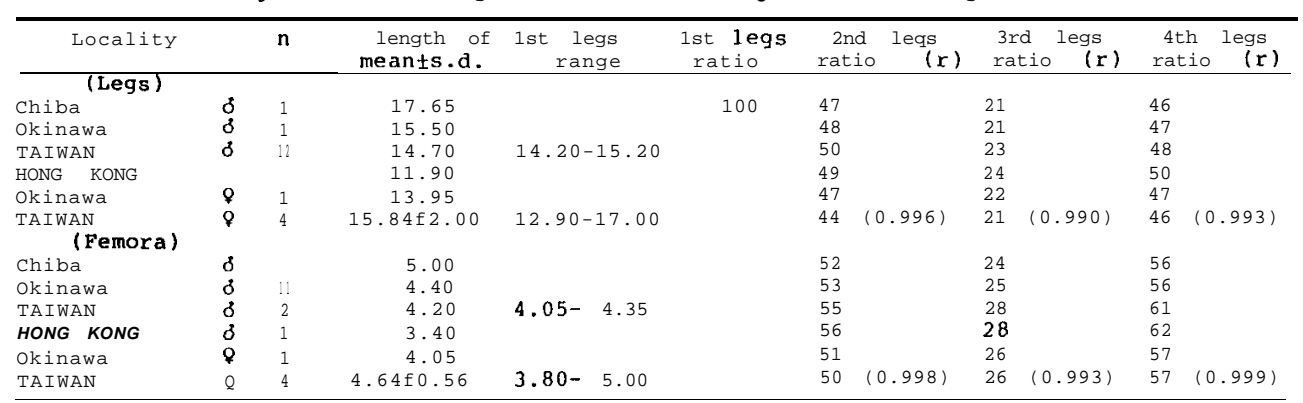

Eyes. Anterior row of eyes occupying full width of head, posterior row of eyes slightly shorter than anterior one ; viewed from above, two rows somewhat strongly recurved, lateral eyes slightly closer than median eyes.

Chelicerae. Basal segment 0.6-0.7 times as long as carapace ; (a) simple, not bifurcated at tip ; $(\mathrm{AXu})$ and $(\mathrm{Gu})$ absent ; (sl) directed forward, (T) somewhat large, (rsu) 3-4 in number; (AXl) absent, (Gl) somewhat robust, (L2) somewhat long, (rsl) about 4 in number ; fang unarmed.

Legs. Leg formula 1. 4. 2. 3 ; all legs without spines ; relative lengths of legs as shown in Table 14.

Palpi. Paracymbium bifurcated at tip; conductor and embolus as shown in Fig. 14, E and F ; distal end of tibia somewhat swollen.

Abdomen. Long, about 3-4 times as long as broad ; rather weak ; distal end of 

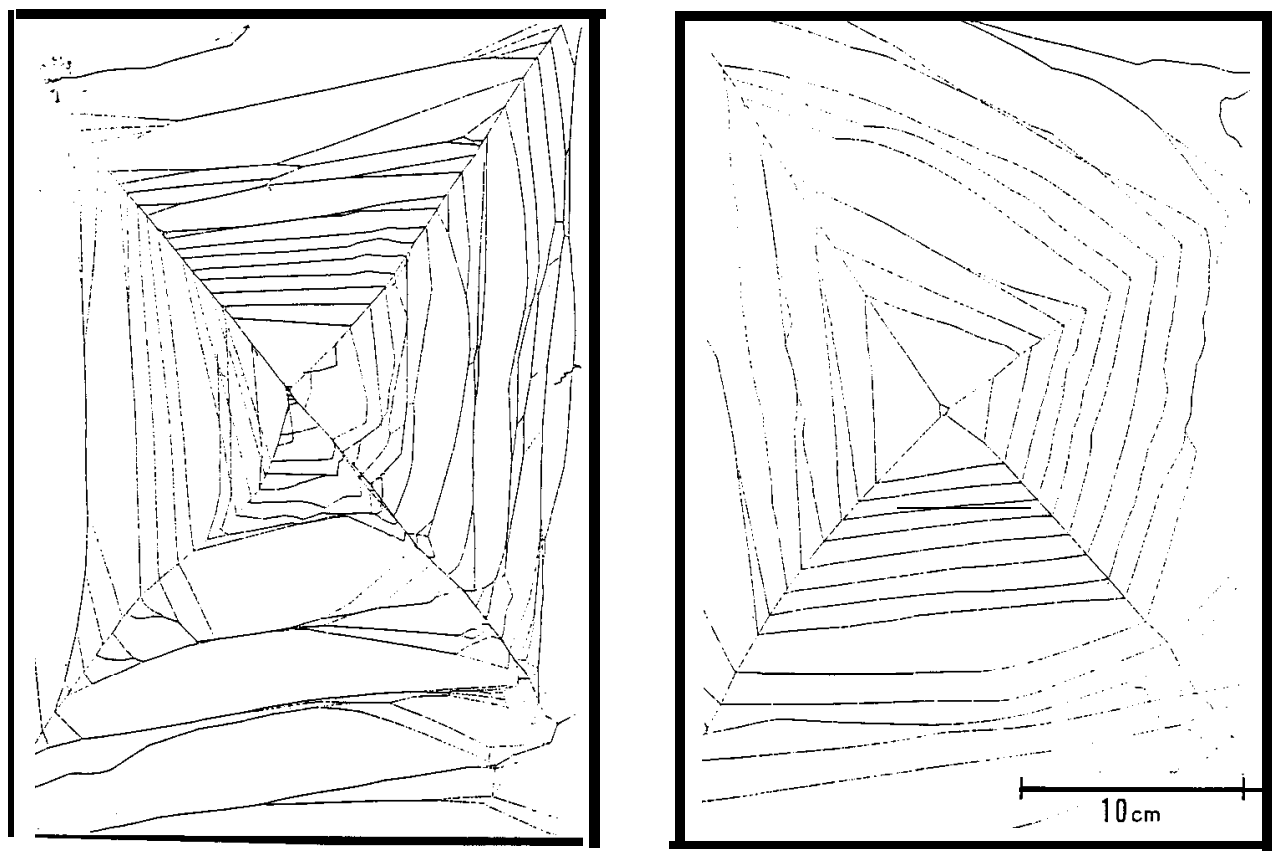

Fig. 15. Horizontal orb (?) webs of Tetragnatha lauta from Chiba Pref., Japan. The radial threads in these webs are only four each. Courtesy of Mr, S. Asama.

abdomen not extended posteriorly to spinnerets.

Color in alcohol. Legs, carapace and chelicerae generally glossy yellowish brown, carapacial sides with longitudinal silvery bands ; abdomen generally grayish brown, with a longitudinal abdominal marking dorsally, and with a central dark gray strip ventrally.

Female. Body length, exclusive of chelicerae 4.6-6.0 mm ; carapacial length 1.4$1.8 \mathrm{~mm}$, width $0.8-1.0 \mathrm{~mm}$, abdominal length $3.2-4.4 \mathrm{~mm}$, width $1.0-1.4 \mathrm{~mm}$, cheliceral length $0.6-0.7 \mathrm{~mm}$.

Eyes. Nearly as in male.

Chelicerae. Basal segment shorter than one-half of carapace ; without paticular features.

Legs. Nearly as in male, relative length of legs as shown in Table 14.

Abdomen. Nearly as in male.

Color in alcohol. Similar to male.

Specimens examined: HONG KONG: 1ð, Tai Po Kaw, 21. IV. 1965, Y. Hirashima. TAIWAN :1 , Fengtien, Pintung Hsien, 12. IV. 1975, Yau I Chu ; $1 \diamond^{ð}, 2$ 우, Hungyehtsun, Taitung Hsien, 2. VI. 1980, H. Makihara ;2 $\sigma^{7}$, Wulai, Taipei Hsien, 27. VI. 1976, H. Makihar. JAPAN :1 $\sigma^{7}$, Kiyosumi yama, Chiba Pref., 29. VII. 1980, K. Suzuki; 2 young, Kamihori, Nobeoka City Miyazaki Pref., 18. VII. 1974, E. Shinkai and S. Matsumoto ;1 $10^{7}$, Hatsuno, Amami oshima, 11. XI. 1962, C. Okuma ;1우, Yona, Okinawa, 25, 26. IV. 1965, H. Hirashima. 
Distribution : Japan, Taiwan (new record) and Hong Kong (new record).

Note : In regard to the webbing habit of this species, very interestingly, it has been frequently observed that the web is composed of only four radial threads as shown in Fig. 15.

\section{The serra-group}

Diagnosis. Posterior row of eyes slightly larger than anterior row of eyes ; central ocular quadrangle nearly square ; female chelicera with long (s) near outer apex ; fang geniculate.

Tetragnatha serra Doleschall, 1857

(Fig. 16, Table 17)

Tetragnatha serra Doleschall, 1857, Naturk. Tijdschr. Ned. Ind., 13 : 408 ; Okuma, 1987, Esakia, (25) : 75.

Additional specimens : THAILAND :1우, Loey, Phuluang, 1,400 m, 16. XII. 1985, T. Sasaki ; 1 우, Khao Yai National Park, 20. I. 1986, T. Sasaki.

Distribution : Java, Sumatra, Sri Lanka, Amboina, New Guinea and Thailand (new record).

Body length : female $8.5-10.0 \mathrm{~mm}$.

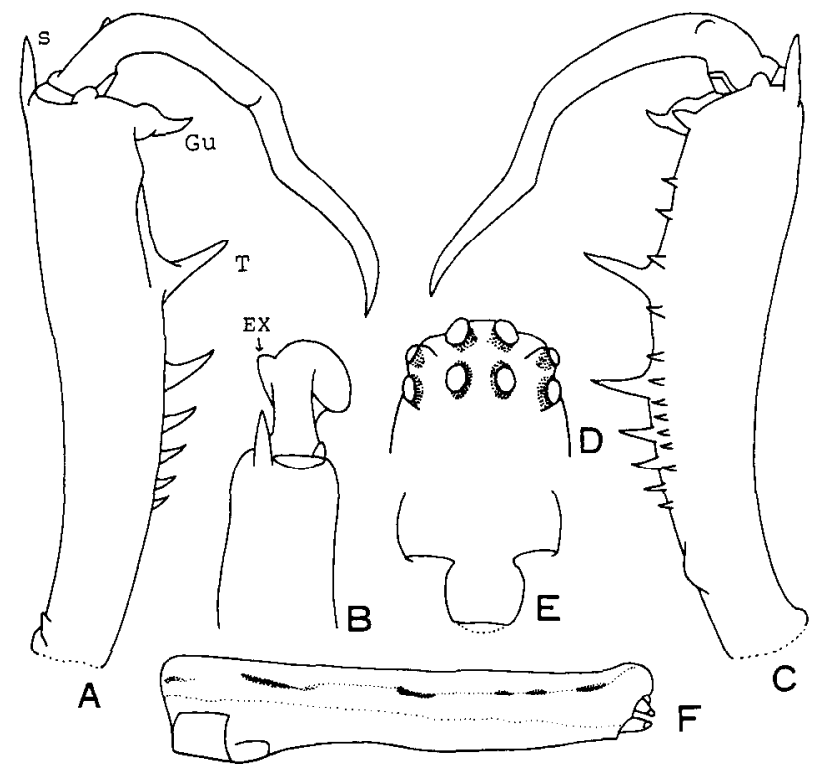

Fig. 16. Tetragnatha serra Doleschall. A : Left chelicera of female, upper view. B : Ditto, lateral view. C : Ditto, lower view. D : Eye group of female. E : Genital fold of female. F : Abdomen of female, lateral view. (After Okuma, 1987). 
Table 17. Tetragnatha serra Doleschall. Relative lengths of total legs and femora.

\begin{tabular}{|c|c|c|c|c|c|c|c|c|}
\hline Locality & & $n$ & $\begin{array}{l}\text { length of } \\
\text { meants.d. }\end{array}$ & $\begin{array}{l}\text { 1st legs } \\
\mathrm{r} \text { a } \mathrm{n} \mathrm{g} \mathrm{e}\end{array}$ & $\begin{array}{c}\text { 1st legs } \\
\text { ratio }\end{array}$ & $\begin{array}{l}\text { 2nd legs } \\
\text { ratio (r) }\end{array}$ & $\begin{array}{l}\text { 3rd legs } \\
\text { ratio (r) }\end{array}$ & $\begin{array}{c}\text { 4th legs } \\
\text { ratio ( } \mathbf{r})\end{array}$ \\
\hline $\begin{array}{l}\text { (Legs) } \\
\text { THAI LAND } \\
\text { (Femora) }\end{array}$ & $Q$ & 2 & 25.25 & $30-27.20$ & 100 & 57 & 25 & 54 \\
\hline THA I LAND & $Q$ & 2 & 7.43 & $6.95-7.90$ & & 61 & 32 & 65 \\
\hline
\end{tabular}

\section{The mandibulata-group}

Diagnosis. Male chelicera without (t) and (T); (a) simple, not bifid at tip ; female chelicera with very strong (AXl) and (Gl); female fang with (EX).

Tetragnatha mandibulata Walckenaer, 1841

(Fig. 17, Table 15)

Tetragnatha mandibulata Walckenaer, 1841, Hist. Nat. Ins. Apt., 2 : 211 ; Okuma, 1983, Esakia, (20) : 70 ; Okuma, 1987 Esakia, (25) : 85.

Additional specimens : BANGLADESH :1 万ొ Mymensingh, 12. IV. 1987, Y. Hirashima;1 $\sigma^{\nearrow}, 1$ 우, 14. IV. 1987, Y. Hirashima. MALAYSIA : $2 \sigma^{\nearrow}$, Alor Sata, III. 1981, K.

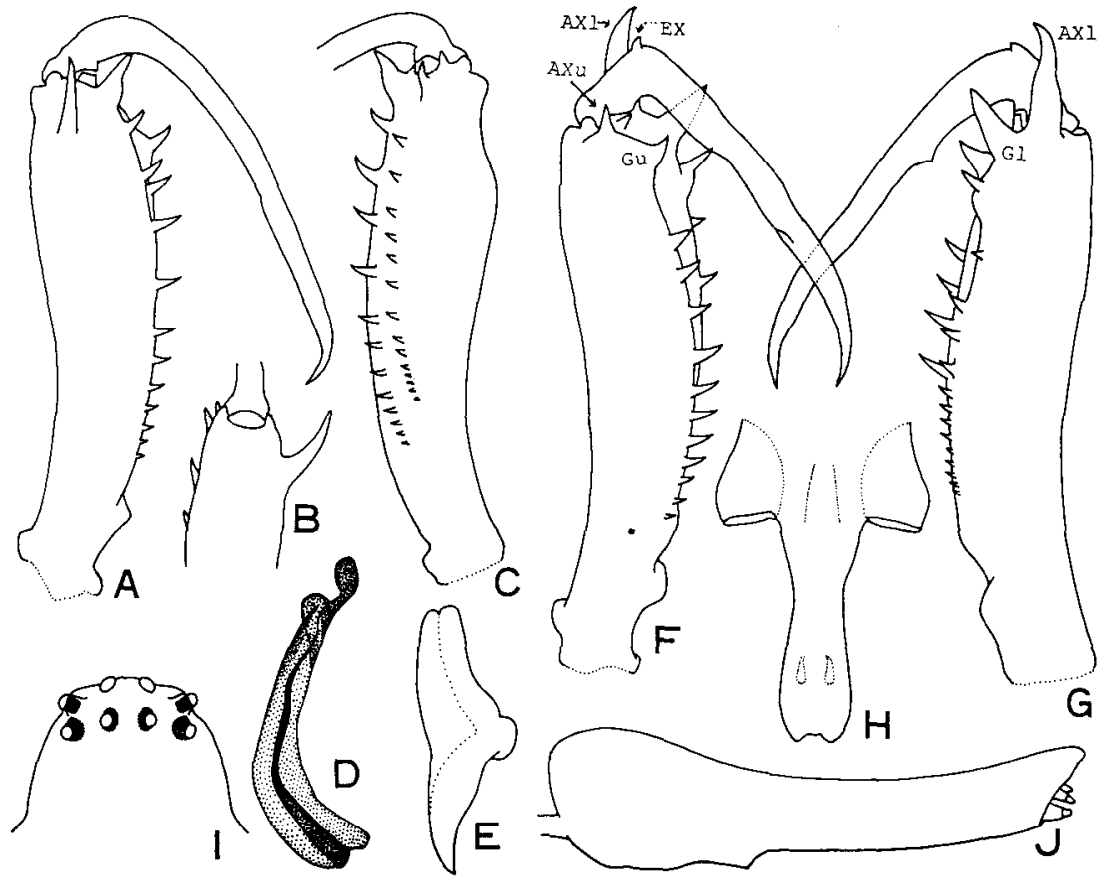

Fig. 17. Tetragnatha mandibulata Walckenaer. A : Left chelicera of male, upper view. B: Ditto, lateral view. C: Ditto, lower view. D: Distal portion of conductor and embolus of male. E : Paracymbium of male. F : Left chelicera of female, upper view. $\mathrm{G}$ : Ditto, lower view. H : Genital fold of famale. I : Eye group of female. J : Abdomen of female, lateral view. (After Okuma, 1987). 
Table 15. Tetragnatha mandibulata Walckenaer. Relative lengths of total legs and femora.

\begin{tabular}{|c|c|c|c|c|c|c|c|c|c|c|c|}
\hline Locality & & $\mathbf{n}$ & $\begin{array}{l}\text { length of } \\
\text { meants.d. }\end{array}$ & $\begin{array}{l}\text { 1st legs } \\
\mathrm{rang} \mathrm{e}\end{array}$ & $\begin{array}{l}\text { 1st legs } \\
\text { ratio }\end{array}$ & $\begin{array}{l}\text { 2nd } \\
\text { rati }\end{array}$ & $\begin{array}{c}\text { legs } \\
\text { ( } 1 \mathrm{r})\end{array}$ & $\begin{array}{l}3 \text { rd } \\
\text { ratio }\end{array}$ & $\begin{array}{l}\operatorname{legs} \\
\text { ( } \mathrm{r})\end{array}$ & $\begin{array}{l}4 \text { th } \\
\text { ratio }\end{array}$ & legs \\
\hline \multicolumn{12}{|l|}{ (Legs) } \\
\hline$J \wedge P \wedge N$ & 8 & 4 & $30.28+2.98$ & $26.45-33.45$ & 100 & 611 & $(0.991)$ & $27 \quad 10$ & .9701 & 59 & $(0.994)$ \\
\hline TATWAN & 8 & 10 & $28.89 f 3.09$ & $26.05-33.35$ & & 591 & 0.9 & 25 & $0.977)$ & 58 & $\begin{array}{l}(0.986) \\
(0.997)\end{array}$ \\
\hline $\begin{array}{l}\text { THATLAND } \\
\text { JAPAN }\end{array}$ & 8 & $\begin{array}{r}10 \\
9\end{array}$ & $\begin{array}{l}29.48 f 4.15 \\
32.02+3.36\end{array}$ & $\begin{array}{l}22.10-33.80 \\
24.16-35.80\end{array}$ & & $\begin{array}{ll}58 & 1 \\
\text { GO } & (1\end{array}$ & $\begin{array}{l}(0.997) \\
(0.992)\end{array}$ & $\begin{array}{ll}25 & 10 \\
28 & 10\end{array}$ & $\begin{array}{l}.986) \\
.983)\end{array}$ & $\begin{array}{ll}57 & 10 \\
60 & 10\end{array}$ & $\begin{array}{l}(0.997) \\
(0.977)\end{array}$ \\
\hline TAIWAN & 0 & 10 & $24.57 f 2.19$ & $21.60-28.60$ & & 601 & $(0.995)$ & $27 \quad 10$ & 0.8301 & $59 \quad 10$ & $(0.991)$ \\
\hline $\begin{array}{l}\text { THAI LAND } \\
\text { (Femora) }\end{array}$ & 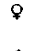 & 10 & $31.77 \mathrm{f} 2.54$ & $27.45-35.80$ & & 59 & $(0.960)$ & 26 & 0.9581 & 58 & $(0.966)$ \\
\hline JAPAN & o & 4 & .91 & $7.30-9.40$ & & 68 & $(0.977)$ & 34 & $0.953)$ & 73 & $(0.989)$ \\
\hline TAIWAN & d & 10 & $7.99 f 0.96$ & $6.10-9.30$ & & 67( & $(0.980)$ & 33 & $0.966)$ & 72 & $(0.977)$ \\
\hline THIAIIAND & 8 & 10 & $8.2 \mathrm{Gf} 1.11$ & $6.25-10.00$ & & 661 & $(0.997)$ & 3310 & $0.985)$ & 71 & $(0.997)$ \\
\hline$J \wedge P \wedge N$ & $Q$ & 9 & $9.16 \pm 0.96$ & $6.90-10.35$ & & 67 & $(0.985)$ & 35 & $0.966)$ & 7310 & $(0.983)$ \\
\hline TAIWAN & 0 & 10 & $7.07 \mathrm{f} 0.63$ & $6.20-8.20$ & & 661 & $(0.984)$ & 34 & $0.928)$ & $72 \quad(6$ & $(0.970)$ \\
\hline THAILAND & $Q$ & 10 & $9.17 f 0.77$ & $7.90-10.30$ & & 651 & $(0.886)$ & 3310 & 0.8511 & $71(0)$ & $(0.869)$ \\
\hline
\end{tabular}

Umeya.

Distribution : W Africa, Bangladesh (new record), SE Asia, Japan (the Ryukyus up to Amami-Oshima), Australia and Polynesia.

Body length : male 8.5-12.0 mm, famale $8.0-13.5 \mathrm{~mm}$.

\section{The maxillosa-group}

Diagnosis. Posterior row of eyes slightly larger than anterior row of eyes ; central ocular quadrangle nearly square ; male chelicera with (a), (t), (Gu) and (T); female chelicera without (e) between $(\mathrm{Gu})$ and $(\mathrm{T})$.

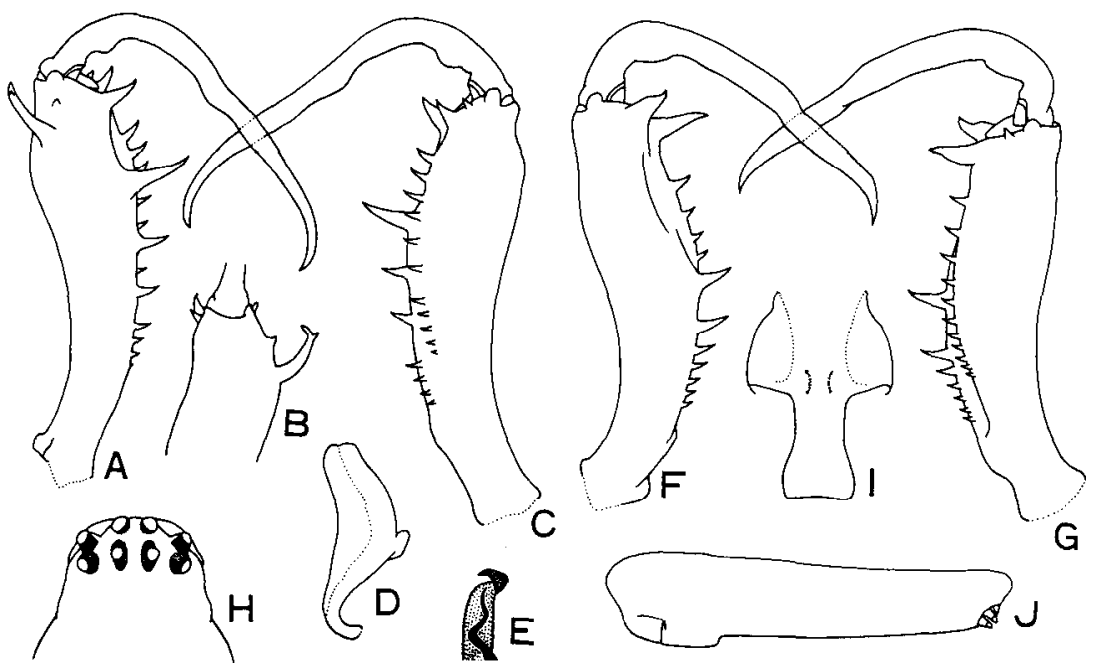

Fig. 18. Tetragnatha maxillosa Thorell. A : Left chelicera of male, upper view. B : Ditto, lateral view. C : Ditto, lower view. D : Paracymbium of male. E : Distal portion of conductor and embolus of male. F : Left chelicera of female, upper view. G : Ditto, lower view. $\mathrm{H}$ : Eye group of male. I : Genital fold of female. J: Abdomen of female, lateral view. (After Okuma, 1987). 
Tetragnatha maxillosa Thorell, 1895

(Fig. 18, Table 16)

Tetragnatha maxillosa Thorell, 1895, Descr. Catal Spid. Burma, : 139 ; Okuma, 1983, Esakia, (20) : 72 ; Okuma, 1987, Esakia, (25) : 83.

Additional specimens : BANGLADESH :1우, Mymensingh, 12. IV. 1987, Y. Hirashima.

Distribution : Widespread in Asia, New Guinea and Africa. This is the first record of the species from Bangladesh.

Body length : male 3.8-10.0 mm, female $6.8-13.5 \mathrm{~mm}$.

The nitens-group

Diagnosis. Male chelicera with three strong apical teeth ; female chelicera with somewhat strong (AXl) and small (Gl); female cheliceral fang with strong (EX).

Table 16. Tetragnatha maxillosa Thorell. Relative lengths of total leqs and femora.

\begin{tabular}{|c|c|c|c|c|c|c|c|c|c|c|c|}
\hline \multicolumn{2}{|l|}{ Locality } & \multirow{3}{*}{$\begin{array}{l}n \\
5\end{array}$} & \multirow{3}{*}{$\begin{array}{c}\begin{array}{c}\text { length of } \\
\text { meants.d. }\end{array} \\
30.47 f 0.47\end{array}$} & $\begin{array}{r}\text { 1st legs } \\
\text { range }\end{array}$ & \multirow{3}{*}{$\begin{array}{c}\text { 1st legs } \\
\text { ratio } \\
100\end{array}$} & \multicolumn{2}{|c|}{$\begin{array}{l}\text { 2nd legs } \\
\text { ratio (r) }\end{array}$} & \multicolumn{2}{|c|}{$\begin{array}{l}\text { 3rd legs } \\
\text { ratio (r) }\end{array}$} & \multicolumn{2}{|c|}{$\begin{array}{l}\text { 4th legs } \\
\text { ratio ( } \mathbf{r})\end{array}$} \\
\hline (Leg & 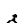 & & & & & & & & & & \\
\hline & $\delta$ & & & $29.95-31.15$ & & 59 & $(0.859)$ & 26 & $(0.921)$ & 58 & $(0.899)$ \\
\hline Tokyo & d & 13 & $23.42 f 5.03$ & $12.95-29.00$ & & 58 & $(0.998)$ & 27 & $(0.994)$ & 58 & 10. \\
\hline Tokushima & 3 & 11 & $28.55 f 4.40$ & $17.35-33.05$ & & 57 & $(0.994)$ & 26 & $(0.987)$ & 58 & $(0.994)$ \\
\hline Fukuoka (May) & d & 8 & $24.91 f 3.19$ & $20.45-28.65$ & & 60 & $(0.986)$ & 28 & $(0.989)$ & 60 & $(0.997)$ \\
\hline ..... (Sep. & 8 & 12 & $23.08 f 5.61$ & $14.45-31.70$ & & 58 & $(0.998)$ & 26 & $(0.998)$ & 58 & $(0.998)$ \\
\hline Yakushima Is. & $d$ & 10 & $27.28 t 5.23$ & $18.95-37.30$ & & 58 & $(0.997)$ & 26 & $(0.993)$ & 59 &.$(0.998)$. \\
\hline Okinawa & 8 & 4 & $20.55 t 3.72$ & $15.40-23.40$ & & 59 & 11. & 27 & $(0.997)$ & 58 & $(0.999)$ \\
\hline ogasawara IS. & $\&$ & 4 & $25.16 f 3.85$ & $20.25-29.65$ & & 60 & $(0.998)$ & 28 & $(0.994)$ & 60 & $(0.999)$ \\
\hline TAIWAN & 8 & 10 & $21.75 f 3.67$ & $14.80-27.55$ & & 58 & $(0.989)$ & 26 & $(0.974)$ & 57 & $(0.988)$ \\
\hline PH I L I P P INES & d & 12 & $22.62 t 2.31$ & $17.40-24.80$ & & 56 & $(0.992)$ & 25 & $(0.977)$ & 57 & $(0.990)$ \\
\hline THA I LAND & d & 10 & $23.52 f 2.66$ & $18.55-27.25$ & & 56 & $(0.994)$ & 25 & 10.9891 & 56 & $(0.983)$ \\
\hline Nigata & & 12 & $27.77-f-2.52$ & $24.90-31.55$ & & 61 & $(0.987)$ & 28 & $(0.984)$ & 57 & $(0.996)$ \\
\hline Tokyo & 8 & 12 & $26.23 f 3.46$ & $17.10-30.25$ & & 61 & $(0.996)$ & 28 & $(0.992)$ & 58 & $(0.993)$ \\
\hline Tokushima & $Q$ & 11 & $27.71 \pm 2.57$ & $21.65-32.00$ & & 60 & $(0.992)$ & 27 & $(0.988)$ & 57 & $(0.981)$ \\
\hline Fukuoka (May) & \& & 7 & $25.70 f 1.78$ & $23.65-28.60$ & & 63 & $(0.979)$ & 29 & $(0.941)$ & 60 & $(0.963)$ \\
\hline . (Sep.) & 8 & 10 & $26.80 f 2.15$ & $23.10-30.85$ & & 60 & $(0.981)$ & 27 & $(0.968)$ & 57 & $(0.973)$ \\
\hline Yakushima Is. & $q$ & 13 & $24.44 f 2.54$ & $20.35-28.25$ & & 60 & $(0.988)$ & 27 & $(0.974)$ & 58 & $(0.984)$ \\
\hline Okinawa Is. & 9 & 10 & $25.71 f 3.67$ & $20.10-32.30$ & & 60 & $(0.996)$ & 27 & $(0.977)$ & 58 & $(0.991)$ \\
\hline Ogasawara Is. & $\psi$ & 14 & $25.46 f 4.16$ & $19.15-32.95$ & & 60 & $(0.996)$ & 28 & $(0.971)$ & 58 & $(0.992)$ \\
\hline TAIWAN & \% & 10 & $24.03 f 2.32$ & $20.40-28.20$ & & 61 & $(0.995)$ & 27 & $(0.989)$ & 58 & $(0.987)$ \\
\hline PHILI PPINES & \% & 13 & $22.54 \pm 1.43$ & $20.65-24.55$ & & 59 & $(0.980)$ & 27 & $(0.942)$ & 56 & $(0.971)$ \\
\hline THAI LAND & $Q$ & 10 & $24.53 \mathrm{f} 2.73$ & $21.05-29.50$ & & 58 & $(0.994)$ & 26 & $(0.991)$ & 55 & $(0.998)$ \\
\hline $\begin{array}{l}\text { SUMATORA } \\
\text { (Femora) }\end{array}$ & 9 & 3 & $22.43 f 2.78$ & $19.70-25.50$ & & 59 & $1 \quad 1$ & 27 & $(0.998)$ & 57 & $1 \quad 1$ \\
\hline Ni igata & 8 & 5 & $8.41 \mathrm{f} 0.21$ & $8.20-8.75$ & & 65 & $(0.641)$ & 34 & $(0.494)$ & 70 & $(0.577)$ \\
\hline Tokyo & $d$ & 13 & $6.48 \pm 1.35$ & $3.70-8.30$ & & 65 & $(0.998)$ & 34 & $(0.996)$ & 70 & $(0.998)$ \\
\hline Tokushima & 0 & 11 & $7.85 f 1.23$ & $4.75-9.25$ & & 64 & $(0.996)$ & 34 & $(0.990)$ & 70 & $(0.994)$ \\
\hline Fukuoka (May) & $d$ & 8 & $6.99 f 0.83$ & $5.80-8.10$ & & 67 & $(0.987)$ & 36 & $(0.975)$ & 72 & $(0.991)$ \\
\hline..,$(\operatorname{Sep})$, & d & 12 & $6.44 \mathrm{f} 1.60$ & $4.00-8.75$ & & 64 & $(0.998)$ & 34 & .10 .9931 & 70 & $(0.998)$ \\
\hline Yakushima Is. & $d$ & 10 & $7.60 \pm 1.48$ & $5.30-10.40$ & & 64 & $(0.996)$ & 34 & $(0.994)$ & 71 & $(0.996)$ \\
\hline Okinawa & $\delta$ & 4 & $5.80 \pm 1.06$ & $4.35-6.70$ & & 64 & 1 & 33 & $(0.999)$ & 71 & 1 \\
\hline ogasawara & 3 & 4 & $7.09 \mathrm{t} 1.14$ & $5.60-8.35$ & & 66 & $(0.995)$ & 35 & $(0.978)$ & 72 & $(0.999)$ \\
\hline TAIWAN & 8 & 10 & $6.36+1.08$ & $4.10-7.70$ & & 64 & $(0.987)$ & 33 & $(0.976)$ & 69 & $(0.988)$ \\
\hline PHILIPPINES & 8 & 12 & $6.38 f 0.65$ & $4.95-7.00$ & & 63 & $(0.987)$ & 32 & $(0.980)$ & 69 & $(0.981)$ \\
\hline THA I LAND & $\delta$ & 10 & $6.57 f 0.76$ & $.05-7.65$ & & 62 & $(0.997)$ & 32 & $(0.989)$ & 68 & $(0.994)$ \\
\hline Niigata & $Q$ & 12 & $8.00 f 0.73$ & $7.20-9.25$ & & 66 & $(0.985)$ & 35 & $(0.982)$ & 69 &. IO. 9871 \\
\hline Tokyo & $\%$ & 12 & $7.54 \pm 0.98$ & $5.00-8.60$ & & 66 & $(0.994)$ & 35 & $(0.985)$ & 70 & $(0.988)$ \\
\hline Tokushima & q & 11 & $7.89 \pm 0.75$ & $6.10-9.10$ & & 66 & $(0.981)$ & 35 & $(0.970)$ & 70 & $(0.950)$ \\
\hline Fukuoka & $Q$ & 7 & $7.49 \mathrm{f} 0.54$ & $6.85-8.30$ & & 67 & $(0.984)$ & 36 & $(0.936)$ & 72 & $(0.958)$ \\
\hline$\ldots \ldots(\operatorname{Sep})$. & $\%$ & 10 & $7.70 \pm 0.63$ & $6.60-8.85$ & & 65 & $(0.987)$ & 34 & $(0.978)$ & 69 & $(0.953)$ \\
\hline Yakushima & $\mathrm{Q}$ & 13 & $6.95 \pm 0.77$ & $5.70-8.05$ & & 66 & $(0.987)$ & 35 & $(0.953)$ & 71 & $(0.983)$ \\
\hline Okinawa & & 10 & $7.38 \pm 1.08$ & $5.80-9.40$ & & 65 & $(0.995)$ & 34 & $(0.982)$ & 70 & $(0.990)$ \\
\hline ogasawara & 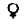 & 14 & $7.38 i 1.19$ & $5.60-9.60$ & & 65 & $(0.997)$ & 35 & $(0.986)$ & 70 & $(0.989)$ \\
\hline TAIWAN & ६ & 10 & $6.83 \pm 0.71$ & $5.90-8.20$ & & 65 & $(0.991)$ & 34 & $(0.971)$ & 69 & $(0.976)$ \\
\hline PHILIPP INES & $\mathrm{Q}$ & 13 & $6.50 \mathrm{f0.42}$ & $5.90-7.05$ & & 64 & $(0.970)$ & 33 & $(0.920)$ & 69 & $(0.960)$ \\
\hline THAILAND & Q & 10 & $E 0.75$ & $6.10-8.50$ & & 63 & $(0.982)$ & 33 & $(0.994)$ & 67 & $(0.990)$ \\
\hline SUMATORA & $\mathbf{Q}$ & 3 & $6.33 \pm 0.81$ & $.60-7.20$ & & 64 & $(1)$ & 34 & $(1)$ & 69 & $(0.999)$ \\
\hline
\end{tabular}




\section{KEY TO THE SPECIES}

1 Relative lengths of legs, from 1 to 4 , as about $100: 62: 27: 57 \ldots \ldots \ldots \ldots \ldots$ boydi

- Relative lengths of legs, from 1 to 4 , as about $100: 68: 30: 63 \ldots \ldots \ldots \ldots$ nitens

\section{Tetragnatha nitens (Audouin, 1827)}

(Fig. 19, Table 18)

Eugnatha nitens Audouin, 1827, Explic. Planch. Arachn. in Savigny, Desc. de 1'Egypt., 22: 323.

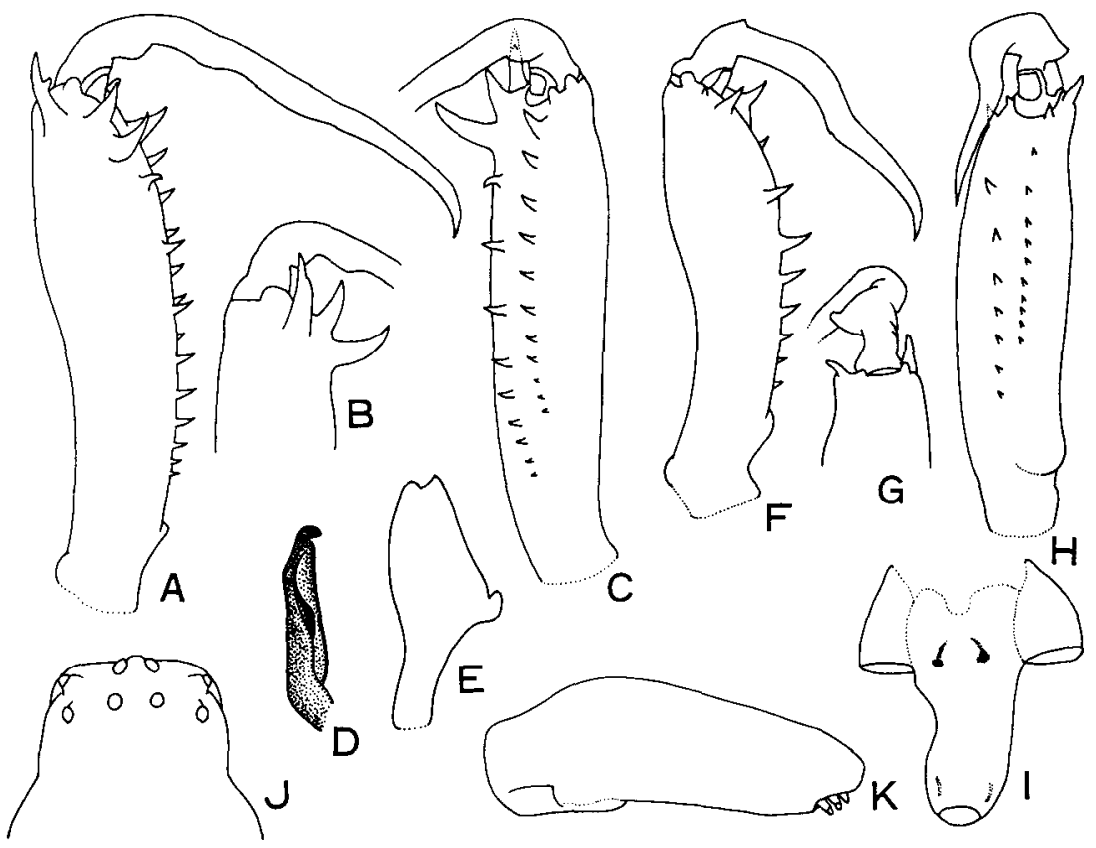

Fig. 19. Tetragnatha nitens (Audouin). A: Left chelicera of male, upper view. B: Ditto, lateral view. C : Ditto, lower view. D : Distal portion of conductor and embolus of male. E : Paracymbium of male. F : Left chelicera of female, upper view. G : Ditto, leteral view. $\mathrm{H}$ : Ditto, inner view. I : Genital fold of female. J : Eye group of female. $\mathrm{K}$ : Abdomen of female, lateral view. (After Okuma, 1987).

Table 18. Tetragnatua nitens (Audouin). Relative lengths of total legs and femora.

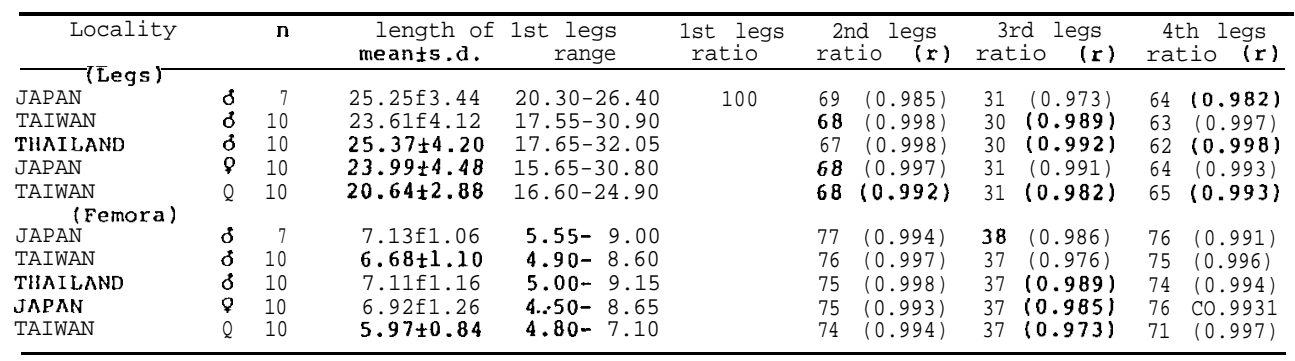


Tetragnatha nitens: Okuma, 1983, Esakia, (20) : 75 ; Okuma, 1987, Esakia, (25) : 84.

Distribution : Pantropical and Pansubtropical.

Note: This species has been known to occur widely in the tropical and subtropical parts of the world. This species is conspicuous in having the spur and the two contignous teeth on the chelicera in the male and the diagnostic posterior cusp on the fang in the female. These characters are very similar to those of T. boydi, so that the two species may be easily confused. However, they are separable by the relative lengths of the legs. Body length : male 7.3-11.0 mm, female $8.5-12.0 \mathrm{~mm}$.

Tetragnatha boydi Cambridge, 1898

(Fig. 20, Table 19)

Tetragnatha boydi Cambridge, 1898, Proc. 2001. Soc. London, : 389 ; Okuma, 1983, Esakia, (20) : 70.

Distribution : Africa, Brazil and Nepal.

Note : According to Dr. Y. Murakami (Kyushu University) who collected this species in Brazil and to Dr. Y. Nishikawa (Ohtemon-Gakuin University) who collected this in Nepal, this species was frequently found on grasses near water.

Body length : male $8.0-8.8 \mathrm{~mm}$, female $8.0-14.2 \mathrm{~mm}$.

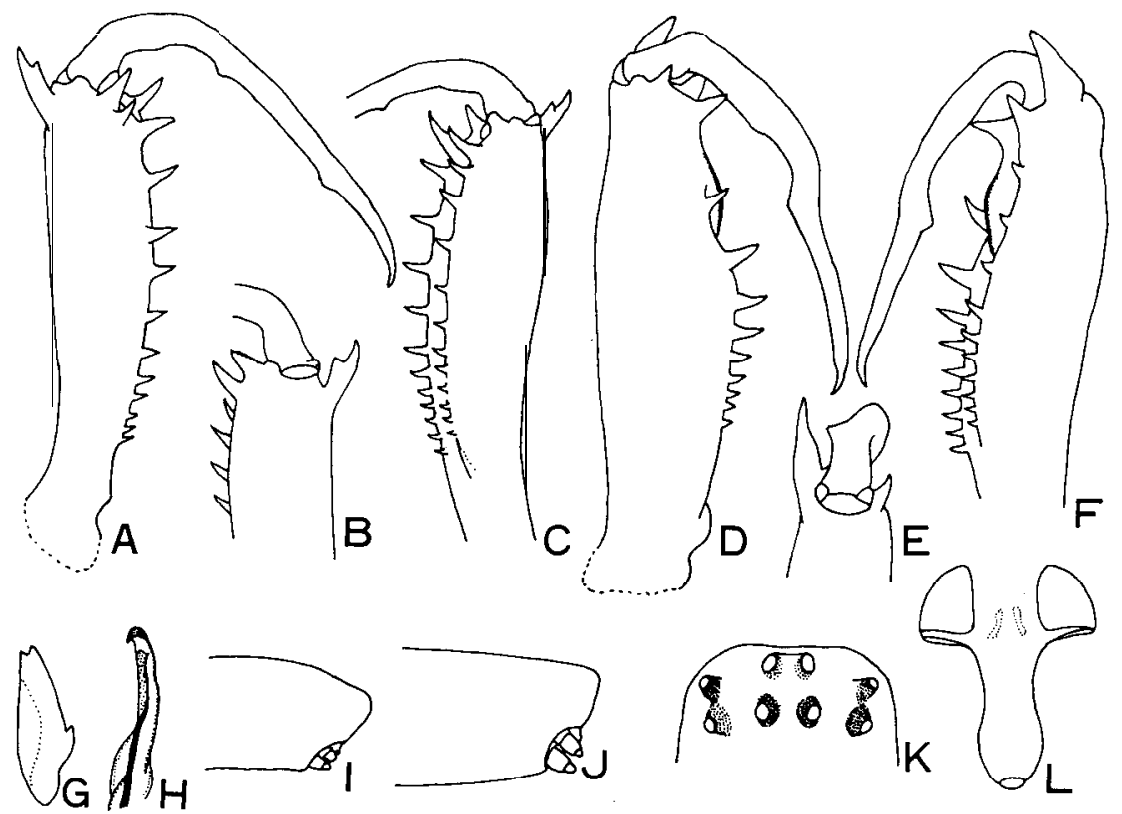

Fig. 20. Tetragnatha boydi Cambridge. A : Left chelicera of male, upper view. B : Ditto, lateral view. C : Ditto, lower view. D : Left chelicera of female, upper view. E : Ditto, lateral view. F : Ditto, lower view. G : Paracymbium of male. H : Distal portion of conductor and embolus of male. I : Distal portion of abdomen of male, lateral view. J : Ditto, female. K : Eye group of female. L : Genital fold of female. (After Okuma, 1983). 
Table 19. Tetragnatha boydi Cambridge. Relative lengths of total legs and femora.

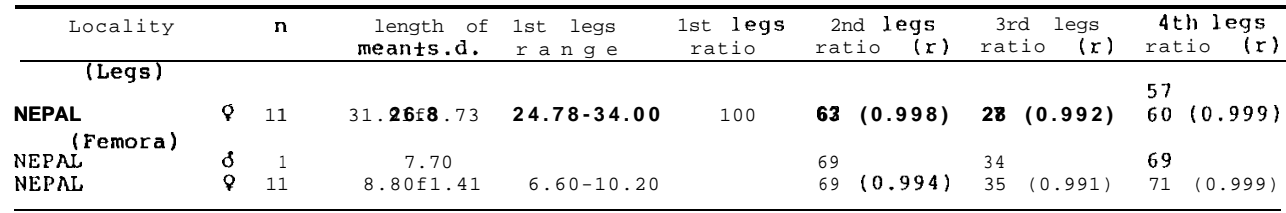

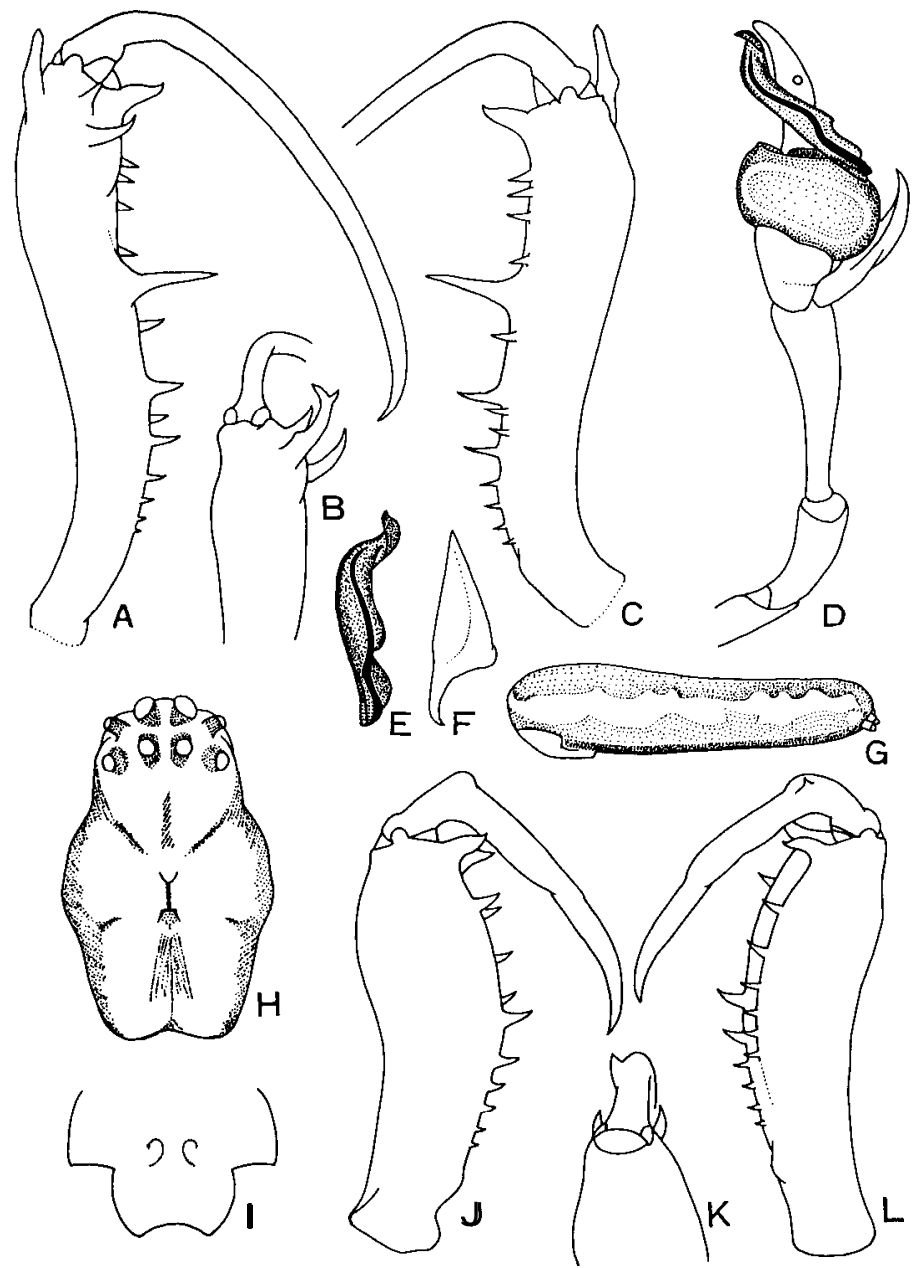

Fig. 21. Tetragnatha josephi Okuma. A : Left chelicera of male, upper view. B : Ditto, lateral view. C : Ditto, lower view. D : Left palpus of male, E : Conductor and embolus of male. F : Paracymbium of male. G : Abdomen of female, lateral view. H : Carapace of male, upper view. I : Genital fold of female. J : Left chelicera of female, upper view. K : Ditto, lateral view, L : Ditto, lower view. (After Okuma, 1988). 


\section{The josephi-group}

Diagnosis. Two rows of eyes equal or subequal in width; abdomen about 3-5 times as long as broad; male chelicera longer than carapace and with three strong teeth at upper apex and with conspicuous long (T).

\section{Tetragnatha josephi Okuma, 1988}

(Fig. 21, Table 20)

Tetragnatha josephi Okuma, 1988, Esakia, (26) :76.

Distribution : Singapore.

Note: The upper distal portion of male chericere in this species is similar to $T$. nitens (Audouin) for the arrangement of three strong teeth, but is easily separable from nitens by having the large and long $(\mathrm{T})$ on the upper margin of fang groov. It is also strikingly different from the congenric species of Tetragnatha by the shape of the male palpal paracymbium and conductor. Body length : male 5.5-5.8 $\mathrm{mm}$, female 6.6-9.7 $\mathrm{mm}$.

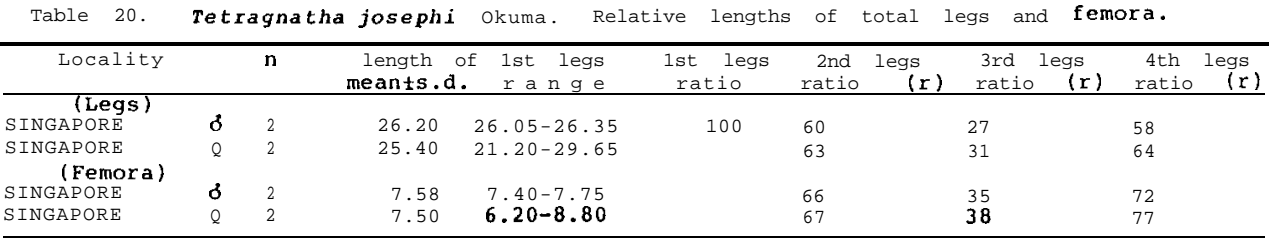

\section{REFERENCES}

Audouin, V. 1827 Explication Sommaire des Planches d'Arachnides, Descr. de 1' Egypt., 22 :291430

Berland, L. 1929 Araignees. in : Insects of Samoa and Samoan terrestrial Arthropoda, 8 (2) :35-78, F. 1-79. London

- 1942 Polynesian spiders. Occ. Pap. B. P. Bishop Mus., 17 (1) : 1-24

Boesenberg, W. und E. Strand 1906 Japanishe Spinnen. Abh. Senckenbg. Nat. Ges., 30 (I-2) : 93-373, T. 3-16

Brignoli, P.M. 1983 A Catalogue of the Araneae described between 1940 and 1981.755 PP. Manchester Univ. Press

Cambridge, 0. P. 1869 Descriptions and sketches of two new species of Araneida. J. Linn. Soc. Lond., 10: 398-405, T. 14

1898 On a collection of Insects and Arachnids made in Socotra. Proc.Zool.Soc. London : $387-391$, T. 31

Chamberlain, R. V. 1924 Descriptions of new American and Chinese spiders, with notes on other Chinese species. Proc.U.S. Nat. Mus., 63 (13): I-38

Chrysanthus, P. 1963 Spiders from South New Guinea V. Nova Guinea, (N. S., Zool.) 24: 727-750

- 1975 Further notes on the spiders of New Guinea II (Araneae, Tetragnathidae, Theridiidae). Zool.Verhandl., Leiden, 140: 3-50

Chu, Y. -1. and C. Okuma 1970 Preliminary survey on the spider-fauna of the paddy field in Taiwan. Mushi, 44 (9) : 65-88

Dalmas, M. 1917 Araignees de Nouvelle Zélande. Ann. Soc. Ent. France, 86 : 417-430, F. 1-76 
Doleschall, L. 1857 Bijdrage tot de Kennis der Arachniden van den Indischen Arachipel. Naturk. Tijdschr. Ned. -Ind., 13: 339-434, T. 1-2

1859 Tweede Bijdrage tot de Kinnis der Arachniden van den indischen Arachipel. Acta Soc. Sci.Ind.-Neerl., 5 : I-60, T. 1-17

Dondale, C. D. 1966 The spider fauna of deciduous orchards in the Australian Capital territory. Aust. J. Zool., 14: 1157-1192

Emerton, J. H. 1884 New England spiders of the family Epeiridae. Trans. Connect. Acad. Arts Sci., 6: $295-341$

Gravely, F. H. 1921 Some Indian spiders of the subfamily Tetragnathinae. Rec. Ind.Mus., 22: 423-459

Hasselt, A. W. M. 1882 Araneae. Midden Sumatra, IV. $3^{\text {de }}$ Aflev. Naturlijke Historie., Part II A : 1 -56, Pl. I-V. Leiden

Hingston, R. W. G. 1927 Protective devices in spiders' snares, with a description of 7 new species of orb-weawing spiders. Proc. Zool. Soc. Lond. : 259-293, F. 1-21

Hogg, H. R. 1914 Spiders from the Montebello Islands. Proc. Zool. Soc. Lond. : 69-92, T. 1-2

— 1915 Report on the spiders collected by the British Ornithologists' Union Expedition and the Wollaston Expedition in Dutch New Guinea. Trans. Zool.Soc. Lond., 20 (14) : 425-484. F. 20-37

Karsch, F. 1891 Arachniden von Ceylon und von Minikoy gesammelt von den Herren Doctoren P. und F. Sarasin. Berlin. Ent. Zeitschr., 36 (2) :267-310, T. 10-12

Keyserling, E. V. 1865 Beitrage zur Kenntniss der Orbitelae Latrl. Verh.zool.-bot. Ges. Wien, 15 : 799-856, T. 18-21

-.- 1887 Die Arachniden Australiens, II : 153-232, T. 13-20. Niirnberg

Koch, L. 1867 Beschreibung neuer Arachniden und Myriapoden, Verh.zool.-bot. Ges. Wien, 17 : 173-250

1870 Beitrage zur Kenntniss der Arachnidenfauna Galiziens. Jahrb. k. k. Gelehr. Ges. Krakau, 41: $1-56$

-1871-1872 Die Arachniden Au\&aliens, I : 1-368, T. 1-27. Niirnberg

Kulczyński, W. 1911 Spinnen aus Nord-Neu-Guinea, in : Res. Exped. Sci. Wichmann. Nova Guinea, 5 (Zool. 3) : 423-518, T. 19-20

-- 1911 Spinnen aus Süd-Neu-Guinea, in: Res. Exped. Sci. Lorentz. Nova Guinea, 9 (Zool.2): 109-148, T. 4

1911 Symbola ad fauna Aranearum Javae et Sumatrae congnoscendam II. Bull. Acad. Cracovie: 451-496, T. 21

Lawrence, F. 1936 Scientific Results of the Vernay-Lang Kalahari Expedition, March to September, 1930. Spiders (Ctenizidae excepted). Ann. Transv. Mus., 17 (2) : 145-158, F. 8

Lessert, R. de 1915 Arachnides de l'Ouganda et de l'Afrique oriental allemande. R ev. suisse Zool., 23 (1): 1-89, 1 fig.

Merian, P. 1911 Die Spinnenfauna von Celebes. Zool. Jahrb. Syst., 31 (2) : 165-354, T. 3

Okuma, C. 1968 Preliminary survey on the spider-fauna of the paddy field in Thailand. Mushi, 42 (8) : 89-118, Pls. 8-13

— 1968 Two spiders new to fauna of Japan. Acta Arachnol., 21 (2) : 40-42, Pl. 1. (In Japanese)

1970 Preliminary survey on the spider-fauna of the paddy field in Taiwan. Mushi, 44 (9) : 65-88

1976 A new record of a Japanese spider-Tetragnatha ceylonica Cambridge. Atypus, (67) : 4547. (In Japanese)

__ 1977 A new species of the genus Tetragnatha (Araneae : Tetragnathidae) from the Ryukyus, Japan. Acta Arachnol., $27: 27-32$

__ 1979 A new species of the genus Tetragnatha (Araneae : Tetragnathidae) from Tropical Asia. Esakia, (14) : 73-77

- 1980 Notes on a spider, Tetragnatha laqueate L. Koch, 1871 of the Bonin Islands, Japan (Araneae : Tetragnathidae). Esakia, (15) :75-78 
1981 A new species of the genus Tetragnatha (Araneae: Tetragnathidae) from the Bonin Islands, Japan. Esakiu, (17) : 141-147

1983 New synonymies and new records of some cosmopolitan species of the genus Tetragnathu (Araneae : Tetragnathidae). Esukia, (20) : 69-80

1984 Notes on the African species of Tetragnatha (Araneae : Tetragnathidae). Esukia, (22) : 87-93

1985 A new species of the genus Tetragnatha from Africa (Araneae : Tetragnathidae). Esakia, (23) : 41-44

- 1987 A revision of the Australasian species of the genus Tetragnatha (Araneae, Tetragnathidae). Esakiu, (25) : 37-96

1988 Five new species of Tetragnathu from Asia (Araneae: Tetragnathidae). Esakiu, (26) : 71-77

Okuma, C. and Y. Chikuni 1978 A new species of the genus Tetragnatha (Araneae: Tetragnathidae) from Nagano Pref., Japan. Acta Arachnol., 28: 1-7

Okuma, C., M. H. Lee and N. Hokyo 1978 Fauna of spiders in a paddy field in Suweon, Korea. Esakiu, (11):81-88

Okuma, C. and R. Kishimoto 1981 Air borne spiders collected over the East China Sea. Jpn. J.appl. Ent.Zool., 25 : 296-298

Pocock, R. I. 1900 The fauna of British India, including Ceylon and Burma. Arachnida, 279 pp. London

- 1901 Descriptions of some new species of spiders from British India. J. Bombay Nut. Hist. Soc., $13: 478-498$

Rainbow, W. J. 1916 Arachnida from Northern Queensland. Rec. Austral. Mus., 11: $33-64$ and 79-119, T. 14-16 and 21-23

Roberts, M. J. 1985 The spiders of Great Britain and Ireland, Vol. 1. Atypidae to Theridiosomatidae, 1-229. Harley Books, England

1985 Ditto, Vol. 3. Colour plates-Atypidae to Linyphiidae, 1-256. Harley Books, England

Roewer, C. F. 1938 Araneae. in: Résultats scientifiques du voyage aux indes orientales néerlandaises de LL. AA. RR. le Prince et la Princesse Léopold de Belgique. Mem. Mus. hist. nut. Belg., (Hors Série) 3 (19): 1-94, F. 1-71

1942 Kutalog der Araneae I. 1040 pp. Bremen

Saaristo, M. I. 1978 Spiders from the Seychelles Islands., with notes on taxonomy. Ann. Zool. Fenn., 15: 99-126

Simon, E. 1890 Arachnides recueillis auxiles Mariannes par M. S.Marche. Ann. Soc. ent. France, $6(10): 131-136$

1894 Histoire naturelle des Araignées 1 (3) : 489-760, F. 491-837. Paris

— 1900 Arachnida. in : Fauna Huwaiiensis, 2 (5) :443-519, T. 15-19. Paris

1901 On the Arachnida Collected during the "Skeat Expedition" to the Malay Peninsula. Proc. Zool. Soc. Lond., 2: 45-84

— 1908 Etude sur les Arachnides du Tonkin. Bull. Sci. Fr. Belg., 42: 69-147

1908 Araneae. $1^{\text {re }}$ Partie. in:Die Fauna Sudwest-Australiens, 1 (12) : 359-446, F.1-4

Strand, E. 1911 Araneae von den Aru-und Kei-Inseln., Abh. senckenbg. Naturf Ges. $34:$ 127-199, T. 4-6

1913 Neue indo-australische und polynesische Spinnen des senckenbergischen Museums. Arch. Naturg., 79 A (6): 113-123

1915 Indoaustralische, papuanische und polynesische Spinnen des senckenbergischen Museums, gesammelt von Dr E. Wolf, Dr J. Elbert u. a. Abh. senckenbg. Naturf. Ges., 36 (2): 181-274, T. 13-19

Thorell, T. 1877 Studi sui Ragni Malesi e Papuani I. Ann. Mus. civ. stor. nat. Genova, 10 :341-634

1878 Ditto, II. Ibid., 13: 1-317

1881 Ditto, III. Ibid., 17: 1-720 
— 1890 Ditto, IV. Ibid., 28: 1-419

1890 Aracnididi Pinang raccolti nel 1889 dai Signori L. Loria e L. Fea., Ibid., 30 : 269-383

- 1891 Spindler från Nikobnarerna och andra delar of sodra Asien. Kongl. Svenska Vet. -Akad. Handl., 24 (2) : 1-149

1895 Description Catalogue of the Spiders of Burma, 406 pp. London

— 1898 Secondo saggio sui Ragni birmani II. Ann. Mus. civ. Stor. nat. Genova, 39: 271-378

Tullgren, A. 1910 Arachnoidea in :Sjöstedt, Y., Kilimandiaro-Meru Expedition, 3 : 85-172, Pl. I-IV. Stockholm

Urguhart, A. T. 1890 On new species of Araneae. Trans. N. Zeal. Inst., 23 : 128-189, T. 21

Walckenaer, C. A. 1841 Histoire naturelle des Znsectes. Apt\&es, Tome II : 549 pp., T. 16-22. Paris

White, A. 1841 Description of new or little known Arachnida. Ann. Mag. Nat. Hist., 1 (7) : 471-477

Yaginuma, T. 1959 Three new spiders collected by the scientific expeditions of the Osaka Museum of Natural History (Tetragnatha,Cyclosa and Titanoeca). Bull. Osaka. Mus. Nat. Hist., 11 : 11-14. Plate 6

1960 Spiders of Japan in Color, 186 pp. Hoikusha, Japan 1986 Ditto, (New Edition), 305 pp. 1-64 pls. Hoikusha, Japan 